\title{
Biological-Based Produced Water Treatment Using Microalgae: Challenges and Efficiency
}

\author{
Malak Alsarayreh $^{1}$, Fares Almomani ${ }^{1, * \mathbb{C}}$, Majeda Khraisheh ${ }^{1}\left(\mathbb{D}\right.$, Mustafa S. Nasser ${ }^{1,2}$ and Yousria Soliman ${ }^{3}$ \\ 1 Department of Chemical Engineering, College of Engineering, Qatar University, Doha P.O. Box 2713, Qatar; \\ ma1808913@qu.edu.qa (M.A.); m.khraisheh@qu.edu.qa (M.K.); m.nasser@qu.edu.qa (M.S.N.) \\ 2 Gas Processing Center, College of Engineering, Qatar University, Doha P.O. Box 2713, Qatar \\ 3 Department of Biological \& Environmental Sciences, College of Arts and Sciences, Qatar University, \\ Doha P.O. Box 2713, Qatar; yousra@qu.edu.qa \\ * Correspondence: falmomani@qu.edu.qa; Tel.: +974-4403-4140 or +974-6641-3198; Fax: +974-4403-4131
}

check for

updates

Citation: Alsarayreh, M.;

Almomani, F.; Khraisheh, M.; Nasser, M.S.; Soliman, Y. Biological-Based Produced Water Treatment Using Microalgae: Challenges and Efficiency. Sustainability 2022, 14, 499. https:// doi.org/10.3390/su14010499

Academic Editors: Simona Carfagna and Giovanna Salbitani

Received: 19 October 2021 Accepted: 19 November 2021 Published: 4 January 2022

Publisher's Note: MDPI stays neutral with regard to jurisdictional claims in published maps and institutional affiliations.

Copyright: (C) 2022 by the authors. Licensee MDPI, Basel, Switzerland. This article is an open access article distributed under the terms and conditions of the Creative Commons Attribution (CC BY) license (https:/ / creativecommons.org/licenses/by/ $4.0 /)$.

\begin{abstract}
Produced water (PW) is the most significant waste stream generated in the oil and gas industries. The generated PW has the potential to be a useful water source rather than waste. While a variety of technologies can be used for the treatment of PW for reuse, biological-based technologies are an effective and sustainable remediation method. Specifically, microalgae, which are a costeffective and sustainable process that use nutrients to eliminate organic pollutants from PW during the bioremediation process. In these treatment processes, microalgae grow in PW free of charge, eliminate pollutants, and generate clean water that can be recycled and reused. This helps to reduce $\mathrm{CO}_{2}$ levels in the atmosphere while simultaneously producing biofuels, other useful chemicals, and added-value products. As such, this review focuses on PW generation in the oil and gas industry, PW characteristics, and examines the available technologies that can be used for PW remediation, with specific attention to algal-based technologies. In addition, the various aspects of algae growth and cultivation in PW, the effect of growth conditions, water quality parameters, and the corresponding treatment performance are presented. Lastly, this review emphasizes the bioremediation of PW using algae and highlights how to harvest algae that can be processed to generate biofuels for added-value products as a sustainable approach.
\end{abstract}

Keywords: produced water; oil and gas production; BTEX removal; biological treatment; chemical treatment; microalgae; harvesting

\section{Introduction}

Produced water (PW) is comprised of an enormous amount of industrial wastewater (WW) generated from oil and gas extraction [1]. This water naturally occurs within the oil reservoir and is generated during the extraction stage [2]. Approximately 250 million barrels of PW are created every day by oil and gas industries, and more than $40 \%$ of that is released into the environment [3], which represents a serious environmental threat. The composition of PW is determined by the geological age, depth, geochemical composition of the area carrying hydrocarbons, the chemical composition of crude oil and natural gas in the zone, and the chemicals introduced during the exploratory process [4]. There is no constant volume of PW in oil and gas exploration as it is dependent on the geographic location of the field and the geological formation [5]. The constituents in the PW are toxic organic compounds such as benzene, toluene, ethylbenzene, and xylenes (known as BTEX), inorganic compounds such as heavy metals, total dissolved solids (TDS), chemical additives used during the oil production process, polyaromatic hydrocarbons (PAHs), and other pollutants [4-7]. The presence of these components in PW increases its toxicity, creates significant environmental concerns, and reduces the possibility of treating and reusing the water. 
Typically, discharging partially treated PW is allowed in specific standard quantities. However, there is a high possibility that over time this water may cause chronic toxicity, which affects the environmental ecosystem [8,9]. It is expected that the volume of PW will imminently increase due to the expansion of the oil and gas industry. Thus, it is crucial to find an efficient and sustainable mechanism to treat and utilize the PW. Recently, greater attention has been given to the benefits of PW recycling and reuse as well as the importance of developing cost-effective treatment technologies with a low environmental impact [10].

Figure 1 presents the technologies that were studied for the treatment of PW since 2016 [11-14]. The number of papers focusing on each subject was included in parentheses in Figure 1. It was observed that biological-based processes are the main technology used in PW treatment with a total of 274 papers. Additionally, membrane, adsorption, advanced oxidation processes (AOPs), and coagulation and flocculation observed among the most studied technologies with 215, 186, 50 and 47 papers, respectively. Generally, PW treatment is comprised of primary treatment processes, including solid settling, oil separation, emulsion removal using gravity settling, and dissolved air floatation. Conversely, chemical unit operations that include coagulation and flocculation are used to improve contaminant removal by enhancing solid separation. The removal of organic matters is carried out by biological processes via bacterial culture using the traditional activated sludge process. However, the high concentration of organic matter, possible toxicity, and inhibition can reduce the large-scale application of the biological process. Other physicochemical processes such as thermal technologies [9], density separation [2], adsorption technologies [10], membrane filtration technologies [11], chemical precipitation, chemical oxidation, and electrochemical methods $[2,5,10,12]$ were used for PW treatment. The application of these technologies is limited due to the high cost and high energy requirement (e.g., thermal methodologies), extensive formation of sludge, need for the disposal of chemicals (e.g., electrochemical methods), complicated pre- and post-treatment (e.g., thermal methods, membranes, and adsorption), and low efficiency (e.g., membrane and electrochemical methods).
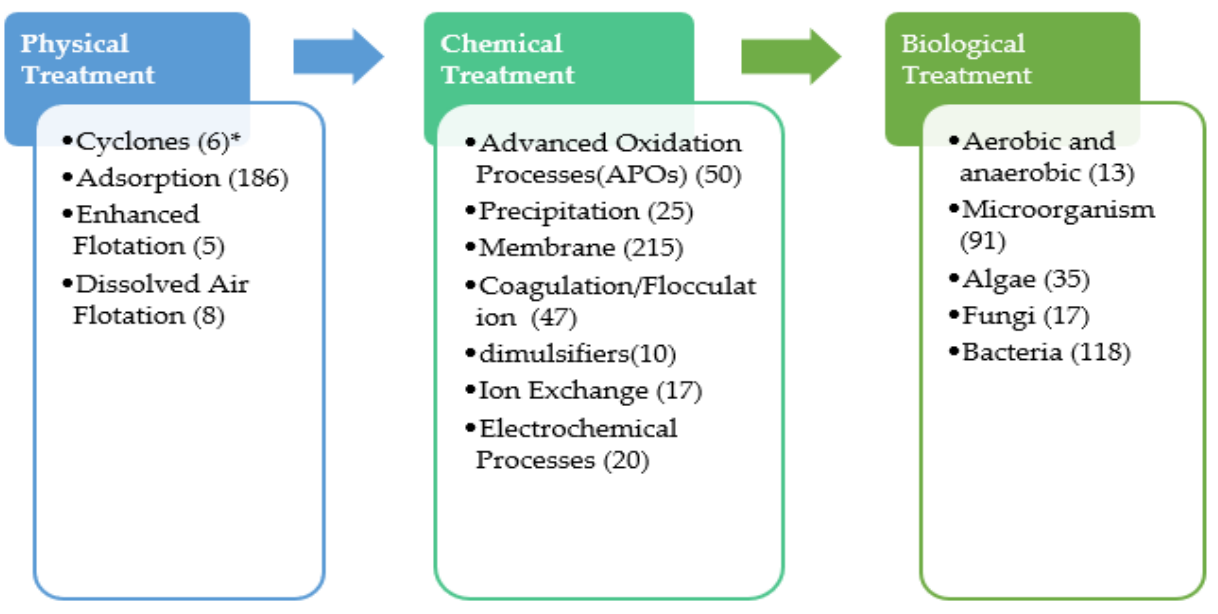

Figure 1. General PW treatment processes. * Number of published papers since 2016.

In contrast, algal treatments are an effective technique to treat a variety of industrial wastewaters [15]. Microalgae can be used to treat PW and remediate organic pollutants with the use of specific algal species. Moreover, microalgae treatment processes produce usable biomass for biofuel production and have an additional benefit of $\mathrm{CO}_{2}$ capturing. In such treatment processes, algal cultures can solve economic and environmental problems while simultaneously producing biofuels and other useful chemicals that reduce $\mathrm{CO}_{2}$ levels in the atmosphere [16]. With an increase in water resource demands, PW has been used to maintain freshwater resources, especially in arid regions suffering from freshwater scarcity. Investigations into the use of algae for PW treatment concluded that it is not sufficiently 
advanced due to a need for large quantities of nutrients, solar radiation, $\mathrm{CO}_{2}$ supply, freshwater, and an adequate area for the cultivation medium $[17,18]$.

To the best of our knowledge, there are no systematic reviews that have comprehensively examined the cultivation of microalgae of PW or reviewed the potential bioremediation and biomass harvesting [1]. In addition, there is a lack of information on the corresponding treatment conditions, including the cultivation process, growth rate, biomass production, and lipid extraction for energy production [1]. Furthermore, there is a limited amount of information on the availability, quality, and toxicity of PW, as well as its impact on microalgae cultivation, or its ability to generate an appropriate amount of biomass for sustainable biofuel production. Thus, the primary goals of this work are to examine the available treatment processes applied for PW treatment, explore the efficiency of algae in treating PW, generate valuable biomass, and identify the common algae species that can be used for PW treatment under different conditions. Lastly, this review highlights algal conditions within the reactor system (open or closed) that can be used to remediate hypersaline PW under high biomass production. This study is unique as it identifies the key processes for promoting algae cultivation in PW. We have complied a list of the algae species outlined in the literature as well as a breakdown of freshwater and marine strains used in PW systems. Furthermore, we provided a list of algae species known to flourish in a wide range of salinities, which can be investigated for use in hypersaline PW treatment.

\section{Methodology}

This review provides an overview of the findings from recent studies between 2016 and 2021. Some important articles published between 1971 and 2021 were also considered as they presented crucial data. Approximately, 294 articles were searched from Web of Science, Google Scholar, ProQuest database, and Produced Water Society (PWS) seminars, with 274 relevant articles kept, and 20 discarded. The keywords used in the search were "produced water", "bioremediation", "biological and chemical treatment", "algae harvesting", "algae cultivation", and "biofuel production". The literature review indicated that algae-based PW treatment systems and PW-based algae cultivation systems are not new, though neither system has received much attention prior to 2014. Further, while the number of research articles produced each year has increased since 2014, the overall efforts have remained modest. In addition to surveys of scholarly research and patents, the expanding number of research publications and citations that serve as markers of the field's growth triggered the current review as well as a desire to understand possible approaches and techniques for PW treatment using microalgae.

\section{Produced Water}

\subsection{Produced Water Generation}

Water created as a by-product during the extraction of oil and natural gas is referred to as produced water (PW). This type of water is frequently found in oil and gas reservoirs, occasionally in a zone underneath the hydrocarbons, and in the same zone as the oil and gas. PW is a type of brackish and saline water that is brought to the surface from underground formations [19]. Typically, oil wells can generate enormous amounts of water together with oil, but gas wells produce water in smaller amounts. In 2018, it was estimated that the production of one U.S. barrel of oil $\left(\approx 0.16 \mathrm{~m}^{3}\right)$ was combined with of 3.13 barrels $\left(\approx 0.50 \mathrm{~m}^{3}\right)$ of PW [4]. This demonstrates that the water to oil ratio is approximately around 3:1. Reports indicate that oil fields account for more than $60 \%$ of PW generation worldwide [4]. Figure 2 illustrates how the age of the oil field directly effects the production rate of the PW [20]. By 2030 , it is expected that the daily crude oil consumption will increase to 106.6 million barrels $\left(\approx 17.10 \mathrm{Mm}^{3}\right)$ in comparison to 85 million barrels $\left(\approx 13.6 \mathrm{Mm}^{3}\right)$ in 2006 [21]. Moreover, by 2030 , the global daily production of PW is expected to reach approximately 246.9 million barrels $\left(\approx 39.50 \mathrm{Mm}^{3}\right)$ [22]. In the United States, the annual production of PW was recorded to be 21 million barrels $\left(\approx 3.40 \mathrm{Mm}^{3}\right)$ in comparison to the 50 million barrels $\left(\approx 8.00 \mathrm{Mm}^{3}\right)$ that has been produced worldwide [23]. 


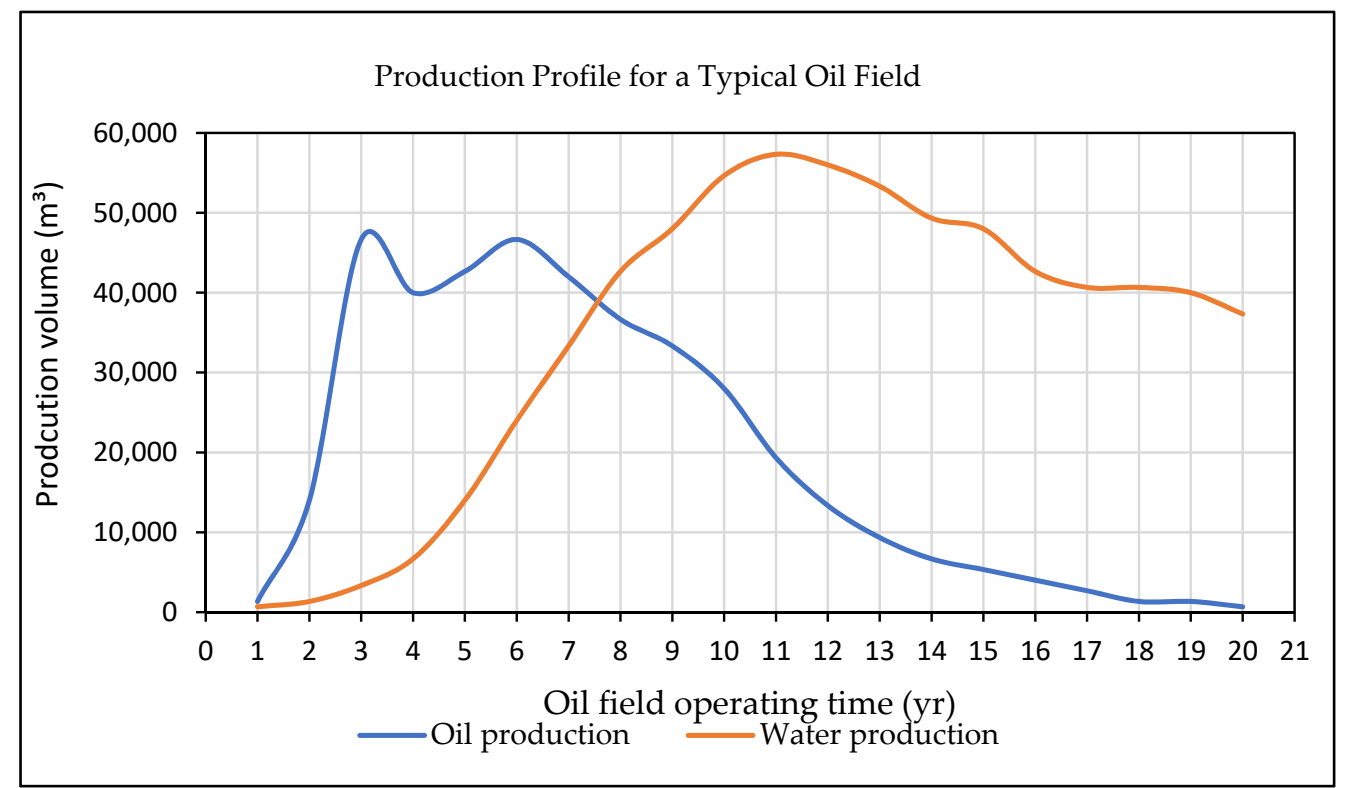

Figure 2. Production of oil and field profile [20].

As previously noted, there is no constant production volume of PW in oil and gas generation, as it is dependent on the geographic location and geological formations [5]. In 2007, the production of crude oil was 53,463.4 barrel/day and 31,449.1 barrel/day of natural gas from the Sergipe and Alagoas oil field in northeastern Brazil was combined with 207,563.8 barrel/day of PW [20]. Only $85 \%$ of the PW was sent to a treatment plant and the remaining was re-injected into the well to help extend the oil field production lifetime [24]. For instance, the U.S. oil industry produces the largest amount of PW [18], with New Mexico as the third-largest oil-producing state in the United States. According to 2019 data, New Mexico produced 1.246 billion barrels of PW [25]. It was reported that Mississippi Oil and Gas generates 330,026,777 bbl/year of PW during gas production [26]. Another large producer is Oman, whose daily extracted volume of PW from Nimr Field reaches $5032 \mathrm{bbl} /$ day [27]. Moreover, Oman's Nimr field can re-inject 120 million L/d of PW into the ground [27]. Moreover, in 2020, Qatar's average production of PW from the offshore North Field produced 26,554 bbl/day [28]. The average water to gas ratio recorded during natural gas generation from Qatar's North Field is 1.2 [28]. These high volumes of PW highlight the urgent need for cost-effective treatment methods. Al-Ghouti et al. [8] characterized Qatar's PW from the Natural Gas Field, which has been outlined in Table 1. Additionally, Table 2 presents the average volume of PW generated in 1998 (557 barrels) to 2014 (23,554 barrels) [29] and 2020 (64,742 barrels) [28].

Table 1. Produced water characterization in Qatar from the Natural Gas field [8].

\begin{tabular}{ccc}
\hline Parameter & Raw Produced Water & Filtered Water \\
\hline Total organic carbon $(\mathrm{mg} / \mathrm{L})$ & 389.1 & 317 \\
Total nitrogen $(\mathrm{mg} / \mathrm{L})$ & 35.77 & 27.6 \\
Total phosphorus $(\mu \mathrm{g} / \mathrm{L})$ & 277.78 & 180 \\
Benzene $(\mathrm{mg} / \mathrm{L})$ & 21 & 16.1 \\
Toluene $(\mathrm{mg} / \mathrm{L})$ & 3.8 & 3.21 \\
Ethylbenzene $(\mathrm{mg} / \mathrm{L})$ & 1.22 & 1.05 \\
Xylene $(\mathrm{mg} / \mathrm{L})$ & 3.43 & 3.11 \\
\hline
\end{tabular}


Table 2. Produced water volume in 1998 and 2014 from different countries.

\begin{tabular}{|c|c|c|c|c|c|c|c|c|c|c|c|}
\hline \multirow[t]{2}{*}{ Country } & \multicolumn{3}{|c|}{$\begin{array}{c}\text { Annual PW Production } \\
\text { (Barrel) }\end{array}$} & \multicolumn{3}{|c|}{$\begin{array}{c}\text { Average Daily PW } \\
\text { (Barrel/d) }\end{array}$} & \multicolumn{3}{|c|}{$\begin{array}{c}\text { The Average Water } \\
\text { to Gas Ratio } \\
\text { (Barrel/MMSCF)* }\end{array}$} & \multirow[t]{2}{*}{$\begin{array}{l}\text { Salinity } \\
\text { Rang } \\
\text { (gTDS/L) }\end{array}$} & \multirow[t]{2}{*}{ References } \\
\hline & 1998 & 2014 & 2020 & 1998 & 2014 & 2020 & 1998 & 2014 & 2020 & & \\
\hline Qatar & $4.1 \times 10^{5}$ & $50.5 \times 10^{6}$ & $58.8 \times 10^{6}$ & $5.6 \times 10^{2}$ & $2.4 \times 10^{4}$ & $6.7 \times 10^{4}$ & 0.36 & 1.2 & 1.60 & 3.9 & {$[28,29]$} \\
\hline Oman & $3.2 \times 10^{6}$ & $5.7 \times 10^{6}$ & $6.9 \times 10^{6}$ & $1.07 \times 10^{4}$ & $1.90 \times 10^{4}$ & $2.7 \times 10^{4}$ & 0.37 & 1.26 & 1.68 & $4.2-9.8$ & [18] \\
\hline $\begin{array}{c}\mathrm{New} \\
\text { Mexico }\end{array}$ & $0.9 \times 10^{9}$ & $1.1 \times 10^{9}$ & $1.25 \times 10^{9}$ & $3.1 \times 10^{5}$ & $3.8 \times 10^{6}$ & $3.9 \times 10^{6}$ & 0.39 & 1.32 & 1.764 & $\geq 100$ & {$[25,30]$} \\
\hline Australia & $2.1 \times 10^{10}$ & $2.52 \times 10^{10}$ & $3.02 \times 10^{10}$ & $7.00 \times 10^{7}$ & $8.40 \times 10^{7}$ & $1.01 \times 10^{8}$ & 0.41 & 1.38 & 1.82 & $2.65-9.09$ & [18] \\
\hline
\end{tabular}

* barrel/MMSCF (barrel/million standard cubic feet).

\subsection{Characteristics of Produced Water}

Produced water characteristics vary between regions and a specific study for each area should be conducted to investigate the effects of PW discharge on the environment $[8,18]$. Further, PW contains a complex composition of physical and chemical properties, dependent on the geological formation, geographic field [5], extraction method, and the type of extracted hydrocarbon [6]. Rahman et al. [1] detail a list of PW parameters and their typical range. It was observed that the toxicity of the PW generated from gas wells is 10 times greater than the toxicity produced from oil wells [5]. Given that, special treatment should be taken for PW from oil wells.

The composition of PW from oil fields is summarized in Table 3. The primary constitutes found in PW are total dissolved solids (TDS), salts, benzene (B), toluene (T), ethylbenzene (E), and xylenes (X) (denoted as BTEX), polyaromatic hydrocarbons (PAHs), oil and grease $(\mathrm{O} \& \mathrm{G})$. The BTEX are volatile organic compounds that naturally occur in oil and gas wells, including gasoline and natural gas. The BTEX compounds also freely escape into the atmosphere during PW treatment [31]. Additionally, traces of natural organic and inorganic compounds, phenol, organic acids, and chemical additives added during the drilling process can be found in PW and contribute to its total toxicity [5].

Table 3. Composition of PW from oil and gas field.

\begin{tabular}{|c|c|c|}
\hline Composition & $\begin{array}{c}\text { Concentration Range } \\
(\mathrm{mg} / \mathrm{L})\end{array}$ & References \\
\hline Chemical oxygen demand (COD) & $1220-2600$ & \multirow{2}{*}[4,6,8,32,33]{} \\
\hline Sodium ions $\left(\mathrm{Na}^{+}\right)$ & $0-150,000$ & \\
\hline Total suspended solids (TSS) & $1.2-1000$ & \multirow{2}{*}[4,6,8,20,32,33]{} \\
\hline Calcium ion $\left(\mathrm{Ca}^{2+}\right)$ & $0-74,000$ & \\
\hline Total polar compounds & $9.7-600$ & \multirow{2}{*}[6,8,34]{} \\
\hline Boron $(\mathrm{B})$ & 5-95 & \\
\hline Total dissolved solids (TDS) & $100-400,000$ & \multirow{2}{*}[8,34]{} \\
\hline Chlorine $\left(\mathrm{Cl}^{-}\right)$ & $0-270,000$ & \\
\hline $\begin{array}{c}\text { BTEX; benzene (B), toluene (T), ethylbenzene }(\mathrm{E}) \text {, } \\
\text { and xylenes }(\mathrm{X})\end{array}$ & $0.73-24.1$ & \multirow[t]{2}{*}[4,32]{} \\
\hline Magnesium $\left(\mathrm{Mg}^{2+}\right)$ & $8-6000$ & \\
\hline Total organic compound (TOC) & $0-1500$ & \multirow{2}{*}[4,6,20,32,33]{} \\
\hline $\operatorname{Iron}(\mathrm{II})\left(\mathrm{Fe}^{2+}\right)$ & $0.1-1100$ & \\
\hline Total oil and grease & $2-565$ & \multirow{2}{*}[34]{} \\
\hline Barium ion $\left(\mathrm{Ba}^{2+}\right)$ & $0-850$ & \\
\hline Phenol & $0.009-23$ & \multirow{2}{*}[6,32,34]{} \\
\hline Potassium ion $\left(\mathrm{K}^{+}\right)$ & $24-4300$ & \\
\hline $\mathrm{pH}$ & $4.3-10$ & \multirow{2}{*}[4]{} \\
\hline Strontium ion $\left(\mathrm{Sr}^{+}\right)$ & $0-6250$ & \\
\hline
\end{tabular}


Table 3. Cont.

\begin{tabular}{ccc}
\hline Composition & $\begin{array}{c}\text { Concentration Range } \\
(\mathbf{m g} / \mathrm{L})\end{array}$ & References \\
\hline Total organic acids & $0.001-10,000$ & {$[4]$} \\
Aluminium $\left(\mathrm{Al}^{3+}\right)$ & $310-340$ & \\
Lithium $\left(\mathrm{Li}^{+}\right)$ & $3-40$ & {$[4,32]$} \\
Lead $(\mathrm{Pb})$ & $0.008-0.08$ & {$[8]$} \\
Bicarbonate $\left(\mathrm{HCO}_{3}^{-}\right)$ & $0-15,000$ & {$[4,6,8]$} \\
Arsenic $(\mathrm{As})$ & $0.002-11$ & \\
Sulfate $\left(\mathrm{SO}_{4}^{2-}\right)$ & $0-15,000$ & {$[4,6]$} \\
Manganese $(\mathrm{Mn})$ & $0.004-175$ & $0.01-0.7$ \\
Titanium $(\mathrm{Ti})$ & $0.01-35$ & \\
Zinc $(\mathrm{Zn})$ & &
\end{tabular}

\section{Treatment of Produced Water}

Although the present work focuses on the treatment of PW by microalgae, a summary of other available technologies is presented and discussed.

\subsection{Chemical Processes}

Table 4 outlines different technologies that have been effectively utilized to remove constituents such as BTEX organic and inorganic matter from PW. For example, advanced oxidation treatment exemplified an excellent performance with a maximum removal efficiency of xylenes and ethylbenzene of 100\% [35]. Sheikholeslami et al. [36] highlighted how photocatalytic degradation using Maghemite nanoparticles removed up to $97 \%$ of BTEX and 95\% of BOD under visible light and ultraviolet irradiation [36]. Zhai et al. [37] used a variety of Fenton processes (i.e., UV-Fenton, US-Fenton, and Fenton treatment) to investigate the optimum conditions for PW treatment and removal of COD, TOC, $\mathrm{BOD}_{5}$, and color. The results exhibited differences in the removal efficiencies in the range of $66 \%$ to 95\% [37]. It was observed that the COD removal efficiency by UV-Fenton, US-Fenton, and Fenton treatments were $82 \%, 79 \%$, and $70 \%$, respectively [37]. Further, TOC removal was $73 \%$ using UV-Fenton, 70\% for US-Fenton, and 58\% for Fenton treatment [37]. Conversely, the removal efficiency for $\mathrm{BOD}_{5}$ was $68 \%$ using UV-Fenton, $66 \%$ using US-Fenton, and $51 \%$ using Fenton treatment [37]. Similarly, $95 \%$ of the color was removed with UV-Fenton, and up to $92 \%$ using Fenton and US-Fenton processes [37]. As a result, the Fenton processes are a promising treatment process for industrial PW [37].

Additionally, Jiménez et al. [38] used advanced oxidation processes for the treatment of PW. The results indicated that naphthalene and BTEX were completely eliminated by AOP processes [39]. However, photocatalysis was shown to be the least effective process for PW mineralization, with TOC reductions below $20 \%$ after $4 \mathrm{~h}$. On the other hand, total TOC removal was achieved by the ozonation process combined with $74 \% \mathrm{H}_{2} \mathrm{O}_{2}$ and $78 \%$ for acetic acid in $2 \mathrm{~h} \mathrm{[38].} \mathrm{The} \mathrm{non-photocatalytic} \mathrm{method} \mathrm{with} \mathrm{synthesized}$ maghemite removed up to $82 \%$ of the BTEX [40]. Jiménez et al. [39] also used bench-scale dissolved air flotation and enhanced dissolved air flotation (E-DAF) to study the settling process and the performance, and AOP to treat $\mathrm{PW}$ for reuse. The results showed turbidity and O\&G removals of $87 \%$ and $90 \%$ with and without air injection, respectively [39]. Zhai et al. [37] used the different Fenton processes to remove color and carbon from PW, which exemplified satisfactory efficiencies. However, the researchers noted that biological treatment is required to reduce the treatment cost and finalize the treatment process. Furthermore, da Silva Almeida et al. [41] utilized a coalescence fibrous media for the separation of the emulsion oil from water. However, this process is not well understood and is often based on observation rather than experimental values [41]. 
Table 4. Technologies used for the treatment of PW with their corresponding efficiency.

\begin{tabular}{|c|c|c|c|c|}
\hline Organic Type & Techniques & $\begin{array}{c}\text { Removal } \\
\text { Efficiency } \%\end{array}$ & $\begin{array}{l}\text { Initial Concentration } \\
\mathrm{mg} / \mathrm{L}\end{array}$ & References \\
\hline BTEX & Nano photocatalytic & $82 \%$ & 600 & {$[40]$} \\
\hline $\begin{array}{l}\text { COD } \\
\text { BTEX }\end{array}$ & $\begin{array}{c}\text { Maghemite nanoparticles visible } \\
\text { light and ultraviolet }\end{array}$ & $\begin{array}{c}95 \%, 96 \% \\
97 \%\end{array}$ & 600 & {$[36]$} \\
\hline $\begin{array}{l}\text { Oil and grease } \\
\text { Oil and grease } \\
\text { phenol }\end{array}$ & $\begin{array}{l}\text { Dissolved air flotation (DAF) } \\
\text { E-DAF: } \\
\text { Fenton and photo-Fenton reactions }\end{array}$ & $\begin{array}{c}87 \%, 90 \% \\
57.6 \%, 73.7 \% \\
>80 \%, 95 \%\end{array}$ & $\begin{array}{l}\text { Oil \&grease: } 150 \\
\text { Phenol: } 50\end{array}$ & [39] \\
\hline $\begin{array}{c}\text { COD } \\
\text { TOC } \\
\text { BOD }_{5} \\
\text { Color removal } \\
\text { COD } \\
\text { TOC } \\
\text { BOD }_{5} \\
\text { Color removal } \\
\text { COD } \\
\text { TOC } \\
\text { BOD }_{5} \\
\text { Color removal }\end{array}$ & $\begin{array}{l}\text { Fenton processes: } \\
\text { UV-Fenton } \\
\text { US-Fenton } \\
\text { Fenton treatment }\end{array}$ & $\begin{array}{l}82 \% \\
73 \% \\
68 \% \\
95 \% \\
79 \% \\
70 \% \\
66 \% \\
95 \% \\
70 \% \\
58 \% \\
51 \% \\
92 \%\end{array}$ & $\begin{array}{l}\text { COD: } 18,825 \\
\text { TOC: } 7217 \\
\text { BOD }_{5}: 1571\end{array}$ & {$[37]$} \\
\hline $\begin{array}{c}\text { Xylenes } \\
\text { Ethylbenzene } \\
\text { Toluene } \\
\text { Benzene }\end{array}$ & $\begin{array}{l}\text { Advanced oxidation treatment } \\
\text { and anodic oxidation (AO) }\end{array}$ & $\begin{array}{c}100 \% \\
90 \% \\
70 \% \\
80 \%\end{array}$ & $0.5,1.25$, and $2.5 \mathrm{mg} / \mathrm{L}$ & {$[35]$} \\
\hline $\begin{array}{c}\text { TOC } \\
\text { Acetic acid } \\
\text { BTEX, naphthalene and phenol } \\
\text { BTEX and naphthalene }\end{array}$ & $\begin{array}{c}\text { Advanced oxidation processes } \\
\text { (AOPs): } \\
\text { Photocatalysis } \\
\text { ozonation combined with } \mathrm{H}_{2} \mathrm{O}_{2} \\
\text { Fenton-based processes } \\
\text { zonation combined with } \mathrm{H}_{2} \mathrm{O}_{2} \\
\text { Fenton-based processes } \\
\text { AOPs processes }\end{array}$ & $\begin{array}{c}20 \% \\
74 \% \\
40 \% \\
78 \% \\
<10 \% \\
\sim 100 \% \\
\sim 100 \%\end{array}$ & $\begin{array}{c}\text { BTEX: } 10 \mathrm{mg} / \mathrm{L} \\
\text { Naphthalene: } 3 \\
\text { PAHs group, phenol: } \\
10 \mathrm{mg} / \mathrm{L} \\
\text { Acetic: } 150 \mathrm{mg} / \mathrm{L} \\
\text { malonic acids: } 10 \mathrm{mg} / \mathrm{L}\end{array}$ & {$[38]$} \\
\hline
\end{tabular}

\subsection{Biological Processes}

The biological treatment of PW can be achieved through bacterial-based biological processes or algae-based biological processes.

\subsubsection{Bacterial-Based Biological Processes}

Biological wastewater treatments are widely used in the treatment of oily water in refineries and storage farms. Activated sludge (AS) is the most commonly used biological technique. In such processes, the dissolved pollutants from PW are consumed by biomass (i.e., sludge) resulting in an effective treatment. Then, water and sludge are removed using a clarified treated effluent. However, the contamination levels and composition in PW vary over time, which causes upset to the biological process. Ultimately, this results in low efficiency and complete shutdowns. Given that, newly developed processes focus on naturally occurring microorganism seeds in produced water. A flexible biofilm can be formed to increase the removal of organic compounds in the oil and gas streams as well as increase the removal efficiency [11]. Moreover, He et al. [42] examined the effectiveness of combining activated sludge with different plants to treat the flow-back-produced water. The researchers used toxicity tests and water quality parameters (COD, BOD, $\mathrm{NH}_{4}-\mathrm{N}$ ) to assess the treatment performance [42]. It was shown that AS is more efficient than prepared microorganisms and the water dropwort plant provides the best option for improving the activated sludge treatment. This process also leads to improved water quality and enhancement in the algal variety [43]. 
Further, Freedman et al. [12] focused on the ability of microorganisms to biodegrade organic carbon with a high concentration of PW using bench-scale and lab-scale biofiltration systems. The bench-scale system exhibited high performance results under a variety of treatment conditions [12]. In other research, Wang et al. [44] exemplified how different types of bacteria, such as Rhodococcus, Thermovirga, and sulfate-reducing bacteria Thermotoga and Petrotoga can effectively degrade hydrocarbons [44]. Camarillo and Stringfellow [15] recorded that up to $69 \%$ of PW treatments were performed in a bench-scale experiment using synthetic WW, and $37 \%$ of the research conducted used real PW. However, a number of studies showed a limited efficiency of bacterial-based processes on the treatment of PW.

Kardena et al. [45] investigated the biological treatment of the synthetic oil field PW in activated sludge to remove organic compounds and determine biokinetic coefficients. The isolated endogenous bacterial strains Pseudomonas sp., Enterobacter sp., Bacillus sp1., and Bacillus sp2. did not achieve more than 82\% COD removal under a high retention time [45]. Although the bacteria grows well in the reactor (as indicated by the high growth rate $(\mathrm{Y})$ value), their low affinity for the substrate causes the COD concentration of effluent to be relatively high [45]. Shwetha et al. [46] reported similar conclusions in their literature review on the treatment of WW from unconventional oil and gas extraction processes.

\subsubsection{Algae-Based Biological Processes}

Microalgae are an encouraging technology for the treatment of WW [47-52]. For example, microalgae can uptake different constituents from PW and use them as a growth medium. Given that, algal cultures can solve both economic and environmental concerns and simultaneously produce biomass and other useful chemicals [53,54]. Establishing a sustainable green technology such as algae for PW treatment, recovery, and reuse contributes to the production of biomass, which can be converted into biofuel [48,54-57]. This conversion helps to eliminate and save natural gas. Moreover, naturally occurring microorganism seeds in PW can sequentially work with algae and increase the removal efficiency of organic matters and dissolved solids. In sequential processes, algae consume $\mathrm{CO}_{2}$ and produces $\mathrm{O}_{2}$, which are essential components for the survival of the microorganism.

Often, pre-treatment is required before mixing PW with algae strains because it contains varying quantities of free oil, dissolved solids, metals, organic pollutants, and volatile organic compounds (VOCs) [18]. A pre-treatment helps to prevent the precipitation of scale-forming minerals that may interfere with algae growth [18]. For example, Al-Ghouti et al. [8] used a $0.45 \mu \mathrm{m}$ Millipore filter to remove suspended particles and other contaminants from a natural gas field in Qatar. Thereafter, the PW was used to cultivate five algae strains that removed heavy metals such as $\mathrm{Al}, \mathrm{Zn}$, and Fe [8]. Godfrey [58] used centrifugation, settling, and activated carbon filtration as a PW pre-treatment process to increase growth rate and lipid productivity. However, as centrifugation is very expensive for a large-scale industrial operation, activated carbon can be used instead. Godfrey [58] also examined two methods of hydrocarbon removal and found that activated carbon filtration was more effective for the removal of hydrocarbons from PW than centrifugation. As such, activated carbon filtration can be a more practical method for removing hydrocarbons in large-scale algae systems using PW.

Ranjbar et al. [59] recommended sterilizing the PW at $121^{\circ} \mathrm{C}$ for $15 \mathrm{~min}$ as a pre-treatment to prevent algal cell inhabitation. However, sterilization is difficult to achieve in a large-scale culture, which makes this step difficult to perform. Instead, Winckelmann et al. [27] grew an indigenous isolate Scenedesmus sp. in open ponds under semi-continuous conditions using pre-cleaned PW. While the pre-cleaning technique was not detailed in the study, the researchers discovered weed algae (i.e., cyanobacteria and diatoms) contamination in the harvested biomass, which negatively impacted the cultures' photosynthetic efficiency over time [27].

Additionally, precipitate formation can be a problem while using PW. For example, Neal et al. [60] cultured Nannochloropsis salina in treated PW from Eldorado Biofuels in Jal, New Mexico and then filtered it through a $0.22 \mu \mathrm{m}$ filter. Without a scaled amount of 
chlorophyll, the researchers observed strong optical density data [60]. This suggests that certain precipitates generated from high sulfate concentrations, as evidenced by scanning electron microscopy (SEM) picture and energy-dispersive X-ray spectroscopy (EDAX) spectra, may have escaped the PW after filtration [60]. Precipitates in PW can adsorb the light that the algae require, which prevents them from growing.

Further, algae can remove various constituents and pollutants from water and wastewater such as nutrients, heavy metals, and dissolved and complex organic chemicals via biosorption and bioaccumulation. Metal biosorption is facilitated by the negatively charged extracellular polymeric substances (EPS) on the surface microalgae [17,61,62]. Microalgae also require some elements, typically found in PW, to grow [5]. The algal approach incorporates resource recovery into the treatment model, which is a sustainable approach for PW remediation. This treatment process produces biomass that serves as raw materials for biofuel, bioactive compounds, and nutrient supplement production.

Table 5 presents the efficiencies of different microalgae strains and their ability to remove organic compounds and nutrients from wastewater. The removal efficiencies reached up to $50 \%, 65 \%$, and $\geq 80 \%$ for nitrogen compounds, phosphorous, and heavy metals, respectively. Other constituent (i.e., COD and BETX) removals were related to the strain that was used. Algae-based wastewater treatment can also be performed in different systems as outlined in Table 6. Depending on the type of system used (i.e., open vs. closed), different removal efficiencies can be achieved.

Table 5. Efficiencies of microalgae in removing organic compounds and nutrients.

\begin{tabular}{|c|c|c|c|}
\hline Microalgae Species & Type of Nutrients & Removal Efficiency\% & References \\
\hline Dunaliella salina & $\begin{array}{c}\text { Nitrogen } \\
\text { Phosphorus } \\
\text { heavy metal: } \\
\mathrm{Ni} \\
\mathrm{Zn}\end{array}$ & $\begin{array}{l}65 \% \\
40 \% \\
90 \% \\
80 \%\end{array}$ & [63] \\
\hline Nannochloropsis oculata & $\begin{array}{c}\text { Ammonium and Nitrogen } \\
\text { Organic carbon } \\
\text { Iron }\end{array}$ & $\begin{array}{c}\sim 100 \% \\
40 \% \\
>90 \%\end{array}$ & [64] \\
\hline Parachlorella kessleri & $\begin{array}{c}\text { Benzene and Xylenes } \\
\text { Toluene } \\
\text { Ethylbenzene }\end{array}$ & $\begin{array}{l}40 \% \\
63 \% \\
30 \%\end{array}$ & [65] \\
\hline $\begin{array}{c}\text { Chlorella vulgaris (C.v) } \\
\text { Neochloris oleoabundans } \\
\text { (N.o) }\end{array}$ & $\begin{array}{c}\text { COD by }(C . v) \\
\text { by (N.o) } \\
\text { Ammonia by C.v. and N.o } \\
\text { Phosphorus by C.v. and N.o }\end{array}$ & $\begin{array}{c}51 \%, 55 \% \text { and } 80 \% \\
63 \%, 47 \% \text { and } 72 \% \\
(70-84 \%) \\
(>84 \%),(>22 \%) \text { and } \\
(<15 \%)\end{array}$ & [66] \\
\hline Chlorella pyrenoidosa & $\begin{array}{l}\text { Chromium } \\
\text { Nickel }\end{array}$ & $\begin{array}{l}11.24 \% \\
33.89 \%\end{array}$ & [67] \\
\hline
\end{tabular}

Table 6. Microalgae cultivation system in different wastewater.

\begin{tabular}{|c|c|c|c|c|c|c|c|}
\hline $\begin{array}{l}\text { Cultivation } \\
\text { System }\end{array}$ & Algae Species & $\begin{array}{l}\text { Cultivation } \\
\text { Condition }\end{array}$ & Type of Waste & $\begin{array}{c}\text { Biomass } \\
\text { Productivity } \\
\text { g/(L.d). }\end{array}$ & $\begin{array}{l}\text { Organic } \\
\text { Removal }\end{array}$ & $\begin{array}{l}\text { Biofuel } \\
\text { Type }\end{array}$ & Refs. \\
\hline $\begin{array}{l}\text { Closed system } \\
\text { (PBRs) }\end{array}$ & $\begin{array}{l}\text { Scenedesmus acutus } \\
\text { (UTEX B72) }\end{array}$ & $\begin{array}{l}\text { Agriculture- } \\
\text { grade urea, } \\
\text { triple super } \\
\text { phosphate } \\
\text { (TSP), pot ash } \\
\text { and Sprint } 330 \\
\text { (iron chelate) }\end{array}$ & Flue gas & 0.15 & Sulfur, NOx & & [68] \\
\hline
\end{tabular}


Table 6. Cont.

\begin{tabular}{|c|c|c|c|c|c|c|c|}
\hline $\begin{array}{l}\text { Cultivation } \\
\text { System }\end{array}$ & Algae Species & $\begin{array}{l}\text { Cultivation } \\
\text { Condition }\end{array}$ & Type of Waste & $\begin{array}{l}\text { Biomass } \\
\text { Productivity } \\
\text { g/(L.d). }\end{array}$ & $\begin{array}{l}\text { Organic } \\
\text { Removal }\end{array}$ & $\begin{array}{l}\text { Biofuel } \\
\text { Type }\end{array}$ & Refs. \\
\hline $\begin{array}{l}\text { Closed system } \\
\text { 4-L cylindrical } \\
\text { photobioreactor } \\
\text { (PBR) }\end{array}$ & $\begin{array}{l}\text { Mixed culture of } \\
\text { Chlorella vulgaris, } \\
\text { Scenedesmus Obliquus, } \\
\text { Botryococcus braunii, } \\
\text { Botryococcus sudeticus, } \\
\text { and Afrocarpus falcatus }\end{array}$ & $\begin{array}{c}\mathrm{pH}=7 \\
\text { Temp }=25^{\circ} \mathrm{C} .\end{array}$ & & 0.15 & $\begin{array}{l}21,60 \text {, and } 47 \% \\
\text { for protein, } \\
\text { carbohydrate } \\
\text { and DOC, } \\
\text { respectively }\end{array}$ & & [69] \\
\hline $500 \mathrm{~mL}$ glass flasks & Dunaliella tertiolecta & $\begin{array}{c}\mathrm{pH}-8.1 \\
\text { Temp }=24^{\circ} \mathrm{C} \\
\mathrm{f} / 2 \text { medium }\end{array}$ & Real PW & $\begin{array}{c}0.0172 @ \\
\text { salinity } \\
30 \text { gTDS/L } \\
\text { to } 0.0098 @ \\
201 \text { gTDS/L }\end{array}$ & & Biodiesel & [61] \\
\hline \multirow[t]{4}{*}{$500 \mathrm{~mL}$ glass flasks } & $\begin{array}{c}\text { Cyanobacterium } \\
\text { aponinum, } \\
\text { Parachlorella kessleri }\end{array}$ & $\begin{array}{c}\mathrm{pH}-8.1 \\
\text { Temp }=24^{\circ} \mathrm{C}, \\
\mathrm{f} / 2 \text { medium }\end{array}$ & Real PW & $0.113 *$ & & Biodiesel & {$[70]$} \\
\hline & $\begin{array}{l}\text { Synechococcus sp., } \\
\text { Cyanobacterium } \\
\text { aponinum and } \\
\text { Phormidium sp. }\end{array}$ & $\mathrm{pH}=(6-9)$ & BG-11 medium & NA & & Biodiesel & {$[71]$} \\
\hline & $\begin{array}{l}\text { Chlorella sp. and } \\
\text { Scenedesmus sp. }\end{array}$ & $\mathrm{pH}=7.1$ & & $0.115 *$ & $\begin{array}{l}\text { Chlorella sp.: } \\
\text { remove } 92 \% \text { of } \\
\text { the TN and } 73 \% \\
\text { of the TOC }\end{array}$ & & {$[72]$} \\
\hline & Dunaliella salina & $\begin{array}{c}\text { Salinity } \\
\text { 52.7-63.3 g/L } \\
\mathrm{NaCl}\end{array}$ & $\begin{array}{l}\text { Real produced } \\
\text { water }\end{array}$ & NA & $\begin{array}{l}\text { Aluminum, } \\
\text { barium, copper, } \\
\text { magnesium, } \\
\text { manganese, } \\
\text { nickel, and } \\
\text { strontium }\end{array}$ & Biodiesel & {$[59]$} \\
\hline $\begin{array}{l}\text { Horizontal laminar } \\
\text { air flow chamber }\end{array}$ & Chlorella pyrenoidosa & $\mathrm{T}=121^{\circ} \mathrm{C}$ & $\begin{array}{l}\text { Fogg's Medium, } \\
\text { slant culture }\end{array}$ & NA & & $\begin{array}{l}\text { Biofuel and } \\
\text { bioplastic }\end{array}$ & [67] \\
\hline
\end{tabular}

* Calculated value from the presented results.

\section{Perspectives of Microalgae Cultivation}

Microalgae can be cultivated in hot regions at $36{ }^{\circ} \mathrm{C}$ and thrive in multiple environments such as seawater, freshwater, and soil [73]. Microalgae cultivation can be conducted in open ponds or close photobioreactors (PBRs) [74,75]. Microalgae can also be cultivated in wastewater generated from the oil and gas industry as it is resistant to high salinity water [61]. Further, microalgae can remove nitrogen, phosphorus, and organic carbon from wastewater [76].

The algae growth and harvesting process is the greatest challenge for the use of this technology and requires further examination [62]. Fuad et al. [77] reported that algal biomass harvesting costs $20-30 \%$ of the total biomass production costs. However, a wide range of techniques is used for algal harvesting, including flocculation and coagulation, electrocoagulation, filtration, centrifugation, and hybrid methods [62]. The harvesting process can be enhanced by adding a coagulant to neutralize the negative charge on the surface of the microalgae and increase the chance of algal biomass coagulation [78,79]. Alternatively, marine algae are a promising alternative due to the low cost of cultivation. In an appropriate environment, common nutrients are readily available, which makes it more economical and sustainable in comparison to freshwater [77]. Moreover, algae are an appealing feedstock because of their quick increase in growth rates $[80,81]$. At the same time, algal biomass can be converted into many sources of biofuel [82], biodiesel [83], biohydrogen, and bioethanol [79]. 


\subsection{Algae Cultivation in Harsh Deserts}

Microalgae cultivation technology is fast-developing due to increasing demands to grow algae in large-scale systems to expand biomass production. Microalgae can be a rich source of carbon compounds, which can be utilized in biofuels, health supplements, pharmaceuticals, cosmetic, and animal feedstock. Whether the cultivation system is open or closed, the growth rate under ambient conditions faces numerous challenges, including contaminating issues, maintaining the culture temperature, and optimizing the performance of the cultivation system [84]. As previously discussed, the cultivation and growth of microalgae in wastewater depends on the water quality parameters such as $\mathrm{pH}$ and nutrients $\left(\mathrm{N}\right.$ and $\mathrm{P}$ ), organic matter, adequate light source, $\mathrm{O}_{2}$, and $\mathrm{CO}_{2}$. These parameters are based on the wastewater source as well as the algae species $[52,85,86]$.

Several studies have focused on the influence of the wastewater source (e.g., artificial, municipal, agricultural, or industrial) on nutrient removal, microalgae growth rates, biofuel production, or a combinator thereof [87-90]. Microalgae cultivation in large-scale areas under sunlight and outdoor conditions experiences several difficulties. In the Middle East and Arabian Gulf, the harsh climate and hot desert weather increase the water evaporation rate and change the growth medium constituent concentration. For example, the daily water loss can reach more than $2 \mathrm{~cm}$. Thus, in most systems seawater is added to reserve losses from the medium during the cultivation period [91]. In addition to its ability to treat wastewater, microalgae cultivation is a valuable source for high biomass production in non-arable land and has been used in open systems for algal growth [84] as well as grown in unsuitable areas for irrigation [92].

A number of researchers evaluated the microalgae growth rate performance for treating various types of wastewaters in hot regions at $36^{\circ} \mathrm{C}$. For example, Chlorella vulgaris and Neochloris oleoabundans exemplified promising results for the removal of organic phosphorus, nitrogen, and organic carbon in hot regions under various conditions [66]. Pruvost et al. [84] applied a thermal model in a semi-buried raceway for a microalgae cultivation system in harsh conditions in the Qatar desert under ambient temperatures between 25 and $37^{\circ} \mathrm{C}$ (see Figure 3). The study predicted and calculated the model of thermal system exchanges over a 24-h period during the summer and winter for two microalgae species [84]. Similarly, Al Ghazal et al. [93] cultivated halotolerant Nannochloris sp. in the Qatar desert under solar radiation conditions. The growth rate correlated to lipid production and exhibited a promising growth rate at a high temperature $\left(45^{\circ} \mathrm{C}\right)$ and high salinity (between 35 and $100 \mathrm{ppt)}$ [93]. Moreover, this strain indicated a possible ability to convert its biomass into environmentally friendly alternative biofuels [91,93]. On the other hand, Das et al. [94] used an open raceway system to cultivate a halotolerant Tetraselmis sp. under semi-continuous conditions, which exhibited varying biomass productivity under various salinity ranges. Das et al. [95] also successfully grew marine cyanobacteria, Chroococcidiopsis sp., in a continuous outdoor cultivation system under different conditions. Conversely, Tetraselmis sp. exemplified excellent growth during a year in the Qatari desert under ambient conditions [94].

\subsection{Cultivation Parameters}

For an effective microalgae cultivation system in large-scale PBRs, sufficient amounts of $\mathrm{CO}_{2}$ are required to increase the growth rate [52,68]. Other requirements for well-controlled cultivation conditions include dissolved oxygen, $\mathrm{pH}$, light, and temperature [82]. The biochemical composition of the microalgae varies depending on the species and cultivation conditions. Of equal importance, microalgae culture can be changed by corresponding changes in the growing media conditions. However, the most important factors that directly affect microalgae growth are temperature, light intensity, $\mathrm{pH}$, organic matter, and nutrients [52]. 


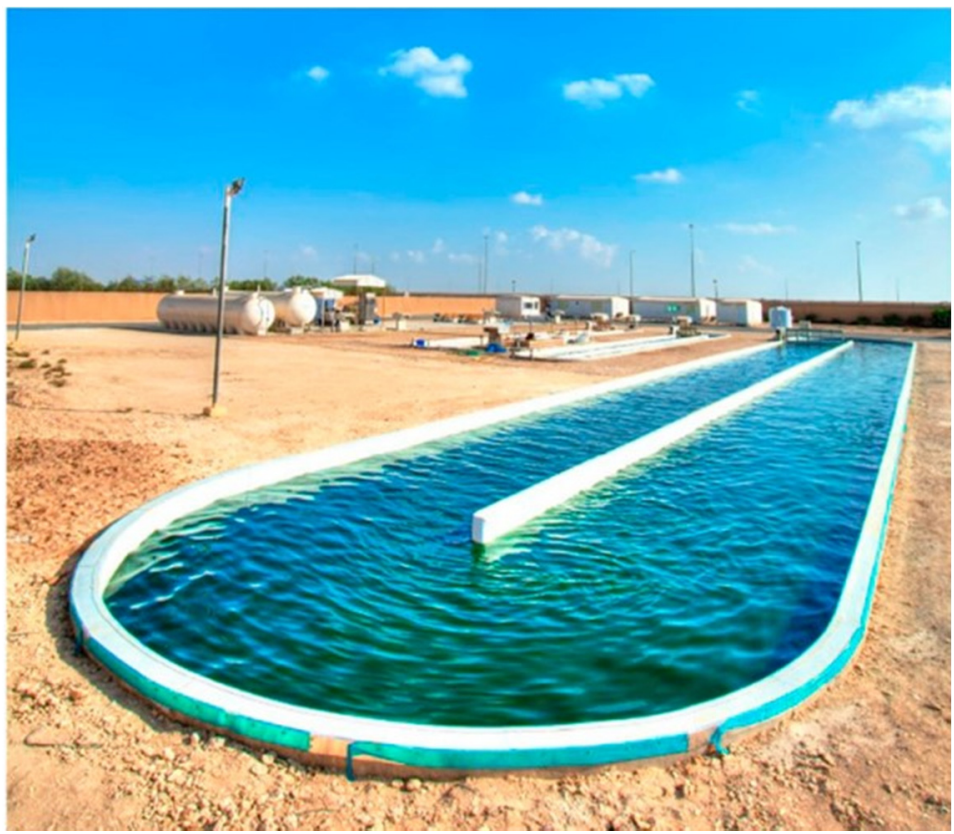

Figure 3. The semi-buried raceway used for microalgae culture in Qatar [84].

\subsubsection{Temperature}

Each microalgae species requires a particular temperature (typically between 20 and $35^{\circ} \mathrm{C}$ ) to achieve optimal growth conditions and maximum biomass production [96,97]; though some algal species can tolerate temperatures up to $40^{\circ} \mathrm{C}$ [97]. For instance, loss of biomass during dark periods was reported to increase at higher temperatures [98]. Arthrospira platensis and mixed algal cultures demonstrated comparable growth within the temperature range of $20-35{ }^{\circ} \mathrm{C}$ [99]. Similarly, Neochloris oleoabundans and Chlorella vulgaris exhibited a promising growth and treatment performance at a temperature of $35^{\circ} \mathrm{C}$ [100]. As such, optimum temperatures in the morning and rapidly declining temperatures after dark must be achieved to sustain and optimize productivity. While algal strains can resist and grow in low temperature environments, temperatures below the optimal range can lead to algal cells dying $[84,101]$. Thus, it is essential to maintain the reactor's temperature within the required range [83].

With respect to the cultivation mode, open ponds do not have temperature control systems to preserve the culture medium's optimal growth rate. This means that in an uncontrolled temperature environment, only robust species can survive. Conversely, in closed systems, the temperature is controllable. Thus, closed systems are appropriate for algal growth that is sensitive to temperature variation [83].

\subsubsection{Light Intensity}

Light availability and intensity (i.e., the primary source of energy for phototrophic algae) are critical components for the growth of algae and biomass productivity [97], as well as key parameters for PBR performance [102]. Natural light is typically used in microalgae cultivation as a cost-effective source that produces natural biomass due to the intensity changes during the daytime and seasonal weather variation [96]. At very low light intensities, the net growth of the algae culture is zero (i.e., compensation point) $[103,104]$. In contrast, photosynthesis accelerates as light intensities rise, until the maximum rate of growth is reached (i.e., saturation point) [105]. However, light intensifying over the saturation point does not boost the growth rate. Instead, high intensity can cause photo damage, a decline in production, and harm the light receptor. Further, damage to the photosynthetic apparatus due to high light intensity combined with increased oxygen levels and suboptimal temperatures can also reduce the growth rate [97]. Given that, it is essential to control sunlight radiation in both open and closed PBRs and monitor the 
forecasted weather conditions [17]. Within this context, it is often difficult and expensive to control outdoor conditions because of the continuous variation in the light intensity during the day. As such, varying light intensities affect the cultivation conditions of the algal pond. Algae can perform photosynthesis in the photosynthetically active radiation (PAR) range of 400-700 nm [102]. The optimal growth rate for Arthrospira platensis and mixed indigenous microalgae were recorded at light intensities in the range of $4.64-8.47 \mathrm{E} \cdot \mathrm{m}^{-2}$ [81]. Light intensities in the range $40-1240 \mu \mathrm{E} \cdot \mathrm{m}^{-2} \cdot \mathrm{s}^{-1}$ provided a reasonable specific growth rate and biomass productivity for Chlorella vulgaris [106-113].

\subsection{3. $\mathrm{CO}_{2}$ and $\mathrm{O}_{2}$ Loading}

During the photosynthesis process, algal cells need carbon dioxide $\left(\mathrm{CO}_{2}\right)$ to grow and produce oxygen. A low atmospheric $\mathrm{CO}_{2}(0.033 \%)$ can inhibit algae growth as approximately $45-50 \%$ of the biomass of algae is comprised of carbon [114]. Given that, the added $\mathrm{CO}_{2}$ should be supplemented. Conversely, when oxygen concentrations in the algae medium surpass saturation, photo-oxidative can damage the chlorophyll reaction centers, which limits photosynthesis and lowers output [115]. However, microalgae can grow in different ranges of $\mathrm{CO}_{2}$ [116]. For example, Cyanidium caldarium can grow in (pure) 100\% $\mathrm{CO}_{2}$ [117], while other species (e.g., Chlorella sp., Euglena gracilis, Scenedesmus sp.) require a maximum $\mathrm{CO}_{2}$ of $<10 \%$ [118-121].

It is not surprising that algae can grow at high $\mathrm{CO}_{2}$ concentrations as the dissolvability of $\mathrm{CO}_{2}$ in water (or water-based mediums) is limited. Though as Douskova et al. [122], Singh and Singh [116], and AlMomani et al. [81] report, not all $\mathrm{CO}_{2}$ added to the culture typically dissolves or is utilized by the strain. Moreover, researchers have highlighted that the dissociation of $\mathrm{CO}_{2}$ in water is $\mathrm{pH}$ dependent [99] with very little $\mathrm{CO}_{2}$ dissolved in an extremely acidic environment. It was reported that some species such as Cyanidium caldarium can grow in $100 \%$ pure $\mathrm{CO}_{2}$, though it is not known how much of the $\mathrm{CO}_{2}$ is dissolved and whether it is bioavailable for algal growth. Moreover, Almomani [99] illustrated how the maximum growth value for a single strain of Arthrospira platensis and mixed culture under natural conditions occurs with a $\mathrm{CO}_{2}(\% \mathrm{v} / v)$ of $12 \%$ and $17 \%$, respectively. The microalgae Chlorella vulgaris exhibited a maximum growth under ambient conditions at a $\mathrm{CO}_{2}(\%$ v/v) of $20 \%$ [99].

Despite the advantages of microalgae, the feasibility of large-scale cultivation requires significant amounts of carbon dioxide $\left(\mathrm{CO}_{2}\right)$ to enable high growth rates [68]. The components required for microalgae biomass are carbon, hydrogen, nitrogen, phosphorus, with small amounts of other elements such as sulfur, potassium, magnesium, and calcium. According to this composition, the culture medium must contain a considerable number of elements to satisfy the maximum culture growth. For economic sustainability, the excess nutrients must be defined, because when nutrients are in excess, they are released and lost from the system [97]. When this occurs, the cultivation medium needs to be recirculated [97]. Given that, several nutrients were introduced into the common culture media, such as Guillard f/2, Algal BBM, BG11, and Zarrouk [123].

\subsubsection{Nutrients}

Aside from macronutrients and organic matter, which are only used in small amounts, algal cultures require different inorganic components that make up the algal cell. The most significant macronutrients are nitrogen $(\mathrm{N})$ and phosphorus $(\mathrm{P})$ (ratio 16:1, N:P) with smaller amounts of sulfur, iron, magnesium, and silicon [123,124]. Growth slows when there is insufficient nitrogen because photosynthetic energy collection is impaired, which lowers the efficiency of the photosynthesis. Instead of photosynthesizing, microalgae cells under N-starvation or N-limitation must relocate resources to support other key cellular activities. Thereafter, the microalgae experiences alterations in pigment compositions, including the loss of chlorophyll and the ability to quickly ingest inorganic nitrogen [125]. Phosphorus is also a key ingredient for cell growth and metabolism in microalgae, as it is a requirement for the formation of organic molecules such as nucleic acid, adenosine 
triphosphate (ATP), and phospholipids [126]. Usually, nutrients are added in excess to avoid nutrient limitation during cultivation because the added nutrients have varying ratios and not all are bioavailable [105].

\subsection{Algae Acclimatization to Produced Water}

Cultivating microalgae in PW with high salinity is a key challenge for algae growth. Typically, PW contains toxic compounds that may inhibit algae growth $[18,127]$. However, the presence of nitrogen and phosphorus in PW can be utilized as a source of nutrients for algal growth and biomass production [127]. Even with a high toxicity and contaminated constituents, oil and gas wastewater exhibited a capability for algal cultivation [18]. The treatment can be successful only for algae species that can resist hypersaline conditions [70]. For example, Dunaliella tertiolecta algae species have demonstrated an efficiency and acclimatization to hypersaline mediums over 210 gTDS/L [128]. Given that, some algae species can be cultivated in PW with high salinity. Cultivation in high salinity will increase the productivity of lipid and biomass density and reduce the demand for $\mathrm{CO}_{2}$ injection to help increase the growth rate [61].

Polyculture algae (e.g., Cyanobacterium aponinum and Parachlorella kessleri) and several halotolerant bacteria species were able to grow in natural oil and gas PW with varying salinities. The influence of growth conditions was compared to growth and lipid formation in polyculture-based PW with varying salinities and initial nutrient concentrations. With a range of salinity levels between 15 and 60 gTDS/L in PW containing nitrate as a source, polyculture algae exemplified growth rates of 46-51 mg ash-free dryer weight (AFDS)/L/D in PW. At a higher salinity, the growth rate decreased. The findings indicated that a mixed culture of C. aponinum and P. kessleri can be used for the production of biomass, biofuels, or both, in brackish-hypersaline PW-based media [70].

More recently, marine algae have gained attention for the treatment of PW. Several marine algae are capable of selectively absorbing heavy metals from aqueous media and accumulating metals within their cells [129,130]. Talebi et al. [63] used marine algae Dunaliella salina in the treatment of PW, biomass production, and lipid extraction. Results indicated that Dunaliella salina can remove $65 \%$ nitrogen, $40 \%$ phosphorus, $90 \% \mathrm{Ni}$, and $80 \% \mathrm{Zn}$ [63]. As a result, lipid productivity values increased (2-3.6 times) and were achieved in saltwater and the PW medium at different ratios (1:1 to 3:1) [63]. Parsy et al. [64] focused on the cultivation of the marine algae species Nannochloropsis oculate in a mixed medium of seawater. The PW, obtained during oil extraction, was mixed with nutrient-rich WW from anaerobic digestions [64]. Further, Nannochloropsis oculate grow quickly in a mixed medium and exhibited an excellent removal efficiency of $\sim 100 \%$ of ammonium and a limited COD removal of $\sim 40 \%$ [64].

Moreover, Hopkins, Graham, and Schuler [61] cultivated Dunaliella tertiolecta in a PW medium over a wide range of salinities (30-210 gTDS/L). The results exemplified a high range of biomass and lipid production that can be used for biofuel production [61]. Pate, Klise, and Wu [128] grew Dunaliella tertiolecta in an oil field PW-based medium over a wide range of salinities (30-210 gTDS /L). The results demonstrated excellent biomass productivity for salinities between the range of 30 and $120 \mathrm{gTDS} / \mathrm{L}$ and a significant growth rate, though the growth rate decreased at salinities between 180 and 210 gTDS/L [128]. The biomass productivity in all PW conditions was higher than in the commercial $\mathrm{f} / 2$ algae growth medium with a salinity of $35 \mathrm{gTDS} / \mathrm{L}$ because of the presence of high concentrations of bicarbonate (20 vs. $2 \mathrm{mM}$ ). Conversely, lower salinity conditions between 30 and 60 gTDS/L generated algal cells with $35-40 \%$ higher total lipid content in comparison to high salinity mediums [61].

Calderón et al. [131] assessed the potential biodegradation of Chlorella vulgaris after cultivation in PW at different concentrations. No significant change in the Chlorella vulgaris was observed [131]. Using 100\% PW in the treatment process exhibited comparable biodegradation to WW containing only 25\% PW [131]. Both WW concentrations exemplified the same cell density and growth rate. The use of microalga cultivation as a sustainable 
wastewater treatment technology also demonstrated promising results. Ojagh et al. [132] discovered that Rhodococcus erythropolis PTCC 1767 can remediate synthetic and real PW with COD, TOC, and hydrocarbon (C14-C26) removal efficiencies of 97\%, 85\%, and 93\%, respectively, at $600 \mathrm{mg} / \mathrm{L}$ of synthetic $\mathrm{PW}$ with a concentration of $60 \mathrm{~g} / \mathrm{L} \mathrm{NaCl}$. Further, a COD removal efficiency of $52 \%$ from PW was a result of adding the remaining cells from the synthetic PW remediation [132]. Further information about algae species that can grow in PW is summarized in Table 7.

Table 7. Algae species adapted to PW.

\begin{tabular}{|c|c|c|c|c|c|c|}
\hline Algae Species & PW Concentration & Medium Culture & $\begin{array}{l}\text { Cultivation } \\
\text { System }\end{array}$ & $\begin{array}{c}\text { Biodegraded } \\
\text { Organic Matter }\end{array}$ & Biomass Production & Refs. \\
\hline $\begin{array}{l}\text { Dunaliella } \\
\text { tertiolecta }\end{array}$ & 30-210 g TDS/L & $\mathrm{f} / 2$ medium & $\begin{array}{c}500 \mathrm{~mL} \\
\text { glass flasks }\end{array}$ & $\begin{array}{l}\text { Nitrogen and } \\
\text { phosphorus }\end{array}$ & $\begin{array}{l}\text { Lipid:35-40\% at } 30 \text { and } \\
60 \mathrm{~g} \text { TDS/L and } \\
\text { Fatty acid methyl ester } \\
\text { profiles (FAME) }\end{array}$ & [61] \\
\hline $\begin{array}{l}\text { Cyanobacterium } \\
\text { aponinum, } \\
\text { Parachlorella } \\
\text { kessleri }\end{array}$ & $\begin{array}{l}15,30,60,75 \\
90 \mathrm{~g} \text { TDS } / \mathrm{L}\end{array}$ & $\mathrm{f} / 2$ medium & $\begin{array}{c}500 \mathrm{~mL} \\
\text { glass flasks }\end{array}$ & $\begin{array}{l}\text { Phosphorus, } \\
\text { ammonium }\end{array}$ & $\begin{array}{l}\text { Lipid production for } \\
\text { biofuel: } 12 \mathrm{mg} \\
\text { lipids / L/D at a salinity of } \\
60 \mathrm{~g} \text { TDS/L }\end{array}$ & [70] \\
\hline $\begin{array}{l}\text { Nannochloropsis } \\
\text { oculata and } \\
\text { Isochrysis galbana }\end{array}$ & $10-50 \%$ & BG11 medium & $\begin{array}{c}250 \mathrm{~mL} \\
\text { Erlenmeyer flask }\end{array}$ & $\begin{array}{l}\text { COD and } \\
\text { oil content }\end{array}$ & $\begin{array}{c}\text {-At } 25 \% \text { PW: } 0.856 \mathrm{~g} / \mathrm{L} \\
\text { and at 50\% PW: } 0.311 \mathrm{~g} / \mathrm{L} \\
\text {-At } 25 \% \text { PW: } 0.638 \mathrm{~g} / \mathrm{L} \\
\text { and at } 50 \% \text { PW: } 0.314 \mathrm{~g} / \mathrm{L}\end{array}$ & [133] \\
\hline $\begin{array}{c}\text { Galdieria } \\
\text { sulphuraria and } \\
\text { Chlorella vulgaris }\end{array}$ & $\begin{array}{c}0 \%, 5 \%, 10 \%, 20 \% \\
50 \%, 100 \%\end{array}$ & $\begin{array}{l}\text { CM Medium, } \\
\text { Bold's Basal } \\
\text { Medium (BBM) }\end{array}$ & $\begin{array}{l}1 \text { L Erlenmeyer } \\
\text { flasks, } 500 \mathrm{~mL} \\
\text { borosilicate } \\
\text { Erlenmeyer flask }\end{array}$ & $\begin{array}{l}\text { Nitrogen and } \\
\text { phosphorus }\end{array}$ & - & [134] \\
\hline Chlorella vulgaris & $\begin{array}{l}0 \%, 25 \%, 75 \%, 100 \% \\
\text { and crude oil }\end{array}$ & F/2 Guillard & 3 L glass flask & $\begin{array}{c}\text { Hydrocarbons } \\
\text { and total phenols, } \\
\text { PAHs }\end{array}$ & - & [131] \\
\hline $\begin{array}{l}\text { Nannochloropsis } \\
\text { oculata }\end{array}$ & $0-50 \%$ & $\begin{array}{l}\text { Mix of seawater } \\
\text { and saline } \\
\text { produced water }\end{array}$ & $\begin{array}{l}500 \text { mL glass } \\
\text { test bottles }\end{array}$ & $\begin{array}{c}\text { Nitrogen } \\
\text { (ammonium) and } \\
\text { chemical oxygen } \\
\text { demand(COD) }\end{array}$ & - & [64] \\
\hline Dunaliella salina & $\begin{array}{l}\text { PW and sea water } \\
(1: 1,1: 2 \text { and } 1: 3, \\
\text { respectively) }\end{array}$ & PW and sea water & - & $\begin{array}{l}\text { Nitrogen, } \\
\text { phosphorus, Ni } \\
\text { and } \mathrm{Zn}\end{array}$ & Lipid and biodiesel & [63] \\
\hline $\begin{array}{l}\text { Rhodococcus } \\
\text { erythropolis } \\
\text { PTCC } 1767\end{array}$ & $600 \mathrm{mg} / \mathrm{L}$ & $\begin{array}{l}\text { Synthetic and } \\
\text { real PW }\end{array}$ & $\begin{array}{l}250 \mathrm{~mL} \\
\text { Erlenmeyer flasks }\end{array}$ & $\begin{array}{l}\text { Total organic } \\
\text { carbon (TOC), } \\
\text { COD, } \\
\text { hydrocarbons } \\
\text { (C14-C26) }\end{array}$ & - & [132] \\
\hline
\end{tabular}

\section{Microalgae Cultivation Systems}

Open and closed systems are the most common type of algae cultivation processes. The open cultivation system is a low-cost operation that produces a large amount of algal biomass without the need for frequent maintenance. However, open cultivation systems have multiple disadvantages, including the need for large quantities of water, large areas of land, high chances for pollution to enter the system, and low biomass productivity [135]. Likewise, it is difficult to remove contaminants from the closed system [136]. As Table 8 outlines, PBRs offer some additional advantages over open ponds.

Open cultivation systems are open ponds and raceway ponds, which provide the best value for the construction cost $[137,138]$ and can be used on a large scale for microalgae cultivation [82]. However, open cultivation systems have several disadvantages: the need for large quantities of water, large land areas, high exposure to pollution, low biomass productivity, loss of algae due to wall-sticking, easy contamination (limiting the system to only a few strains of algae), and difficulty producing long-term algal cultures [73,135,136]. Further, supplying $\mathrm{CO}_{2}$ to open cultivation systems is one of the main challenges facing 
microalgae cultivation because of the high cost of $\mathrm{CO}_{2}$. Additionally, algae farms are affected by restrictions imposed on $\mathrm{CO}_{2}$ emissions [139]. Given that, most microalgae cultivation processes are operated on a lab and pilot scale [140].

Table 8. Comparison between open and closed algal systems.

\begin{tabular}{|c|c|c|}
\hline Culture Medium & Open System & Closed System \\
\hline Land required & Large areas & Depends on PBRs \\
\hline Construction and operation & Easy & Easy-difficult \\
\hline Cost and maintenance & Low cost required & High \\
\hline Light penetration and utilization & Limit light absorption to the culture & Sufficient/depends on PBRs type \\
\hline Biomass productivity & Low and poor productivity & Low-high (depends on PBRs type) \\
\hline Cultivation parameters & Low control strategies of the culture conditions & Easy to control \\
\hline The need for water for operation & Large quantity & Small quantity \\
\hline Seasonal variation & Effected and difficult to control & Not effected and easy to control \\
\hline Algal harvesting from culture & Costly and difficult & $\begin{array}{l}\text { Depends on harvesting techniques } \\
\text { and PBRs type }\end{array}$ \\
\hline Energy consumption & Low energy consumption & High energy \\
\hline Culture contamination & Easy to contaminate and difficult to control & Prevent contamination \\
\hline Evaporation & Very high & Low \\
\hline Algal cultivation density & Low-high & Very high density \\
\hline Loss in $\mathrm{CO}_{2}$ level & Diffuse to the atmosphere & Dissolved in the culture \\
\hline Variation in water quality & High variation in water quality and the growth rates & Low variation \\
\hline Exposure to pollution & High chance of cultures contamination & $\begin{array}{l}\text { Low chance and prevents } \\
\text { culture contamination }\end{array}$ \\
\hline
\end{tabular}

Open systems provide limited $\mathrm{CO}_{2}$ levels, which leads to limited photosynthesis processes and can folate some algal cells on the surface. Alternatively, PBRs exhibited an exemplary ability to monitor $\mathrm{CO}_{2}$ loading, oxygen build-up, and the concentration of the nutrient $[81,83]$. As the optimal light intensity varies between algal species, optimizing light intensity is necessary for algal cultivation [141]. As such, light-an essential component for $\mathrm{CO}_{2}$ adsorption and biomass production-has a limited penetration ability in an open cultivation system, whereas light can enter PBR systems.

Beyond these constraints, microalgae adaption of a single algae strain in an open system is feasible as it is low cost, provides a suitable cultivation environment for high biomass production, and provides high contaminant resistance. It was reported that natural resources can be used as a cultivation medium. For example, wastewater containing urea was used as a cultivation medium to provide essential nutrients for Chlorella sp. and Arthrospira platensis cultivation in outdoor systems [142]. With this combination, the cost of expensive chemicals is greatly reduced. Further, the open pond system achieved $98 \%$ biomass production [143]. Chlorella vulgaris achieved a lipid content production of $3.18 \pm 0.80 \%$ and $2.26 \pm 0.51 \%$ in an open pond and PBR, respectively [144]. The algae strain Nannochloropsis sp. exhibited promising results in a high salinity medium with an average daily biomass production of $20.37 \mathrm{~g} / \mathrm{m}^{2}$ without contaminant exposure [91].

Several types of PBRs were studied and suggested as a way to improve the open system performance at a low cost and high biomass production. Over the last two decades, closed systems have gained numerous improvements $[145,146]$. Using different configurations, PBRs have been operated to achieve an optimum growth rate of algal species with a high biomass production under optimum conditions [83]. A closed PBR system has a compact configuration with a high surface-to-volume ratio that enhances all the growth parameters under optimized conditions. Tubular and flat-plate are the most common types of PBRs, 
which are constructed from transparent, mechanically resistant, chemically stable, and cost-effective durable plastic or glass [147]. Figure 4 highlights the various types of artificial PBRs and their designs (e.g., vertical, tubular, and lab-scale systems) for algal cultivation under specific conditions to detect the optimal biomass production at a low cost [83]. For more types of PBR designs see Lee [148], Richmond [147], and Carvalho et al. [149].

For the configuration, algae and wastewater are pumped through transport tubes and continuously circulated [81]. Continuous pumping (i.e., air bubbling) is commonly used to circulate the algal suspension within the bioreactor [74]. However, cultivation in PBRs has limitations. For instance, fouling or growth on the PBR walls can limit light penetration, which dissolves $\mathrm{O}_{2}$ and $\mathrm{CO}_{2}$, causes $\mathrm{pH}$ gradients, and hydrodynamic shear stress. Taken together, these issues cause damage to the individual cells themselves.

(a)

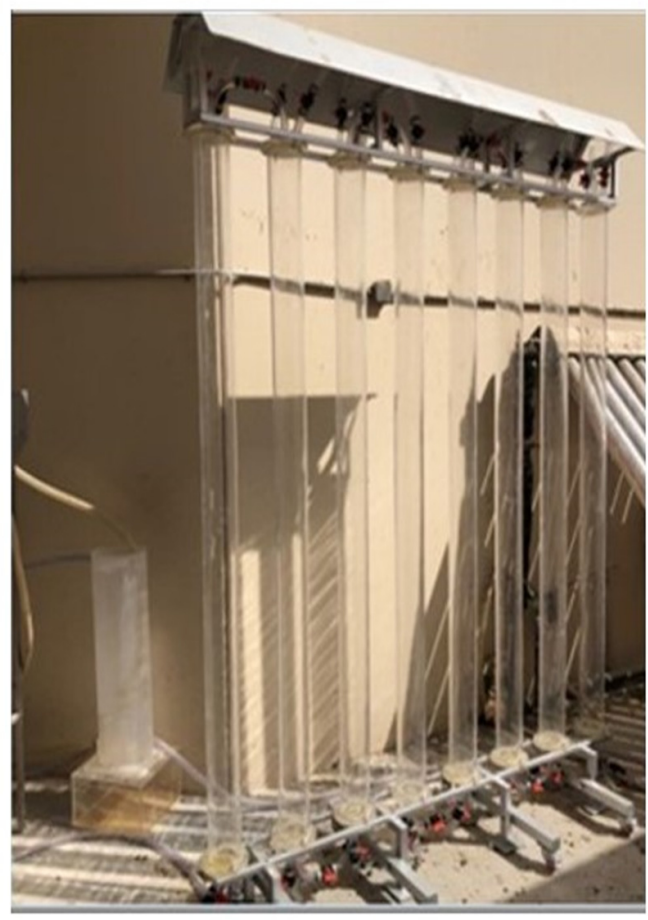

(b)

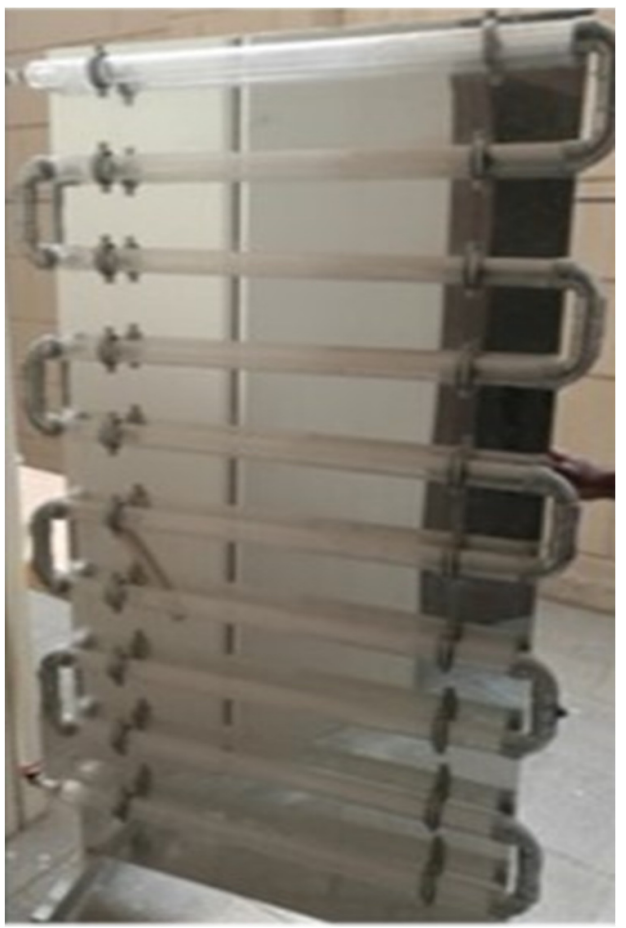

(c)

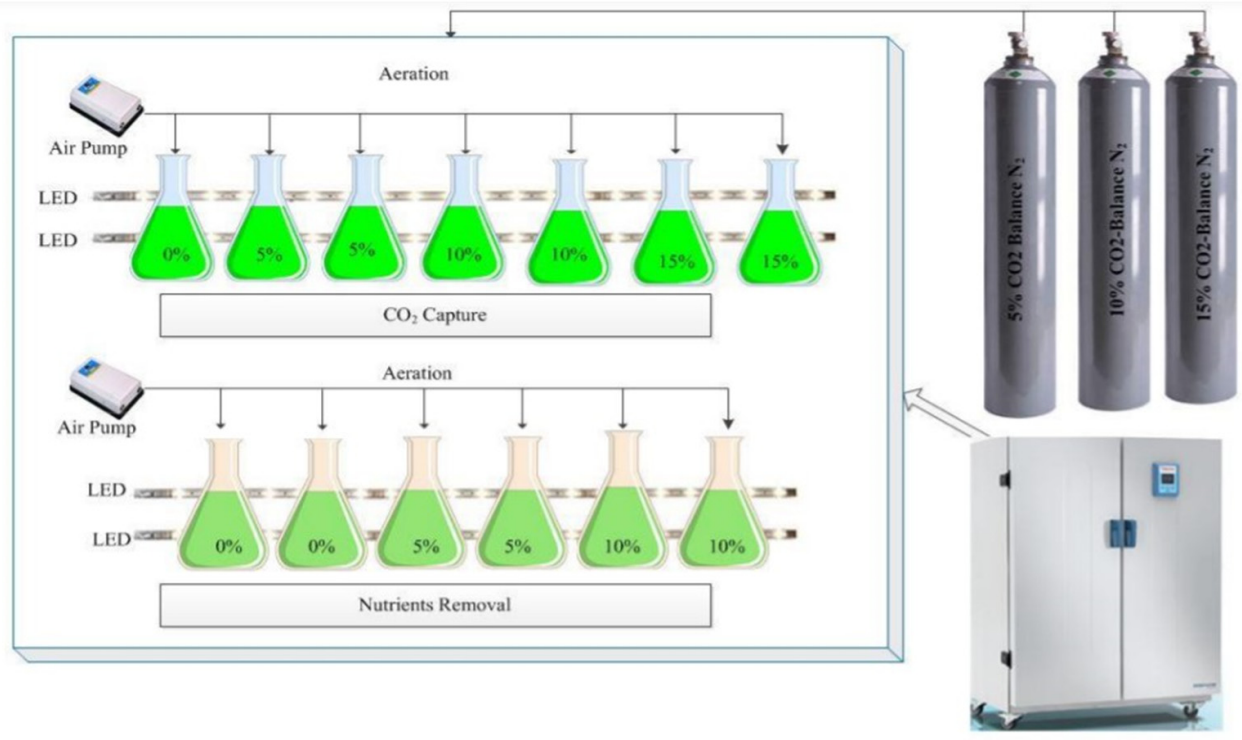

Figure 4. Cont. 
(d)

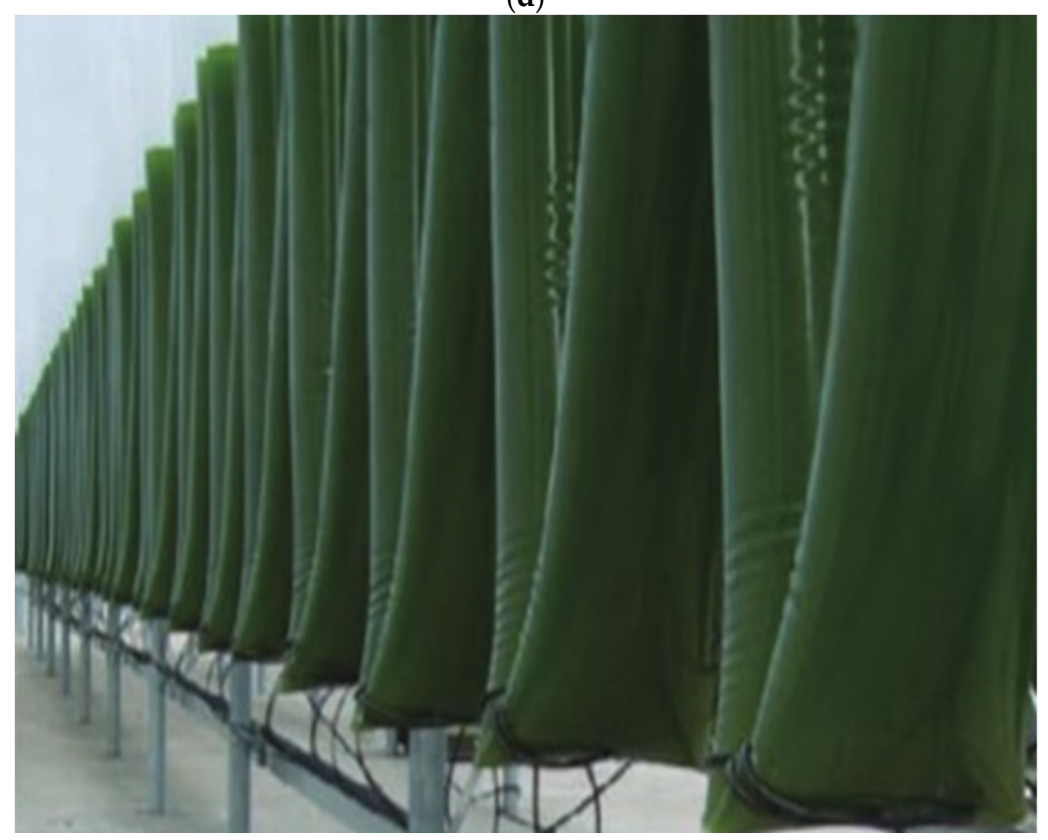

(e)

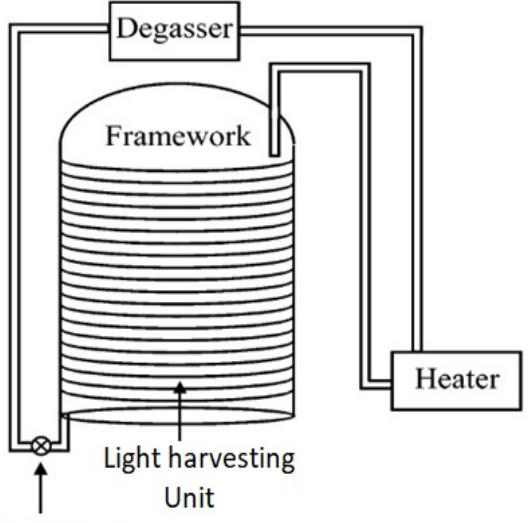

Centrifugal pump (f)

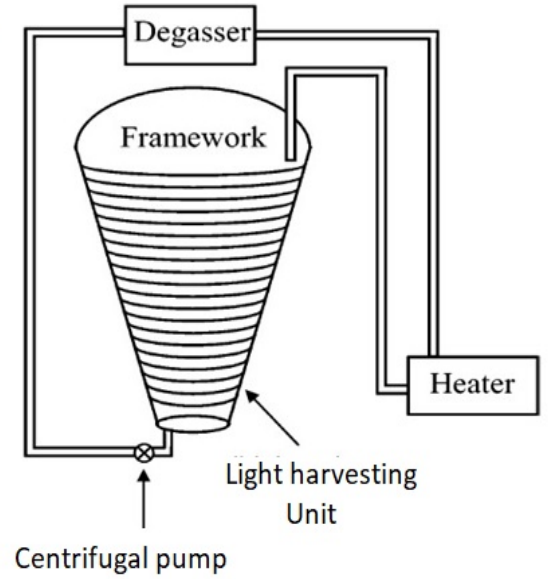

(h)

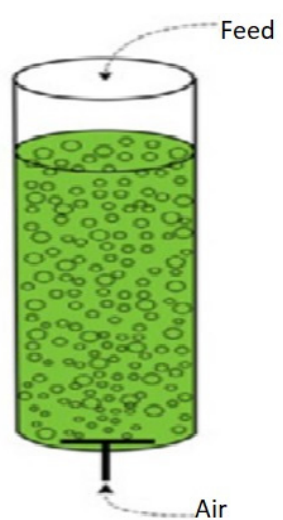

eed (g)

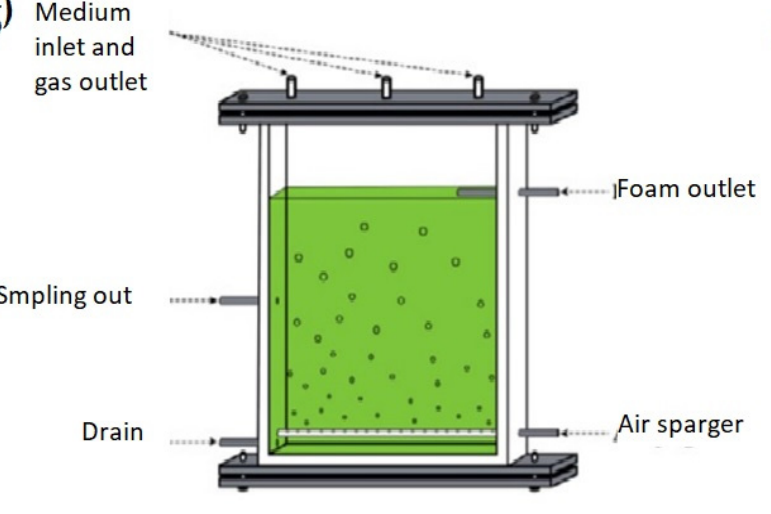

Figure 4. (a) vertical tube pilot PBR, (b) horizontal tubes pilot PBR [81], (c) lab-scale reactors [150], (d) plastic bag PBR [96], (e) tubular reactors (Biocoil helical and horizontal tubes [151], (f) conical framework [149], (g) flat-panel PBR [152], and (h) bubble column PBR [152]. 


\section{Algae Harvesting}

The process of growing, harvesting, and converting algae into fuel and other products in an economically competitive manner is still in the development phase. Effectively harvesting algal biomass (from an optimized cultivation system) facilitates the creation of conversion biofuel. If algal biomass is converted into biofuel, it can compete with petroleum-based fuels due to low-carbon energy indices. Algal capture carbon as lipids, which is an increasingly recognized alternative to direct atmospheric $\mathrm{CO}_{2}$ capture and sequestration. However, it is a challenge to find the most successful algal production system for commercially viable industrial applications. However, many algae species have self-precipitating capabilities, making them easier to collect with little to no need for expensive equipment and chemicals.

During and following the treatment process of PW, the accumulated biomass must be harvested and removed from the tank. The cell concentration inside the reactor must remain at an approximate predetermined constant value to ensure optimal performance and to avoid problems caused by the overgrowth. Additionally, algal biomass can be used for the production of biofuels due to their fast growth rates [128]. Algae can also grow in multiple mediums and not compete with land crops [143], which makes them a promising feedstock. The synergy between the need to maintain a specified level of microorganisms inside the reactor and the potential use of algae for biofuel production works for a combined treatment-biofuel production process.

The most common algae harvesting methods are summarized in Table 9. Physical harvesting is the preferred method for algae harvesting because of its higher economic efficiency, visibility of large colonies of microorganisms, and density. Filtration, a common process, is highly effective when using larger algal cells as it enables classification according to flow pattern, rate, and filter medium $[153,154]$. With membrane technology, ultrafiltration can perform the same task as filtration as well as include smaller algae, which increases the removal efficiency. However, ultrafiltration has an associated maintenance cost for cleaning the filter.

Centrifugation, the most common method for algae harvesting, is dependent on the centrifugal force applied to the sample. Centrifugation has recovery rates up to and greater than $90 \%$ [155-157]. Depending on the extent of the angular velocity, denser suspended solids (i.e., algae) move to the edge while the lighter water moves in the other direction, achieving separation. In the flotation method, air bubbles are introduced into the tank from below, moving upwards and lifting more of the algae with them to the surface to be collected and skimmed [158]. However, sometimes the algae cells are too small to be separated by physical methods, which can be solved by using chemical harvesting methods. Flocculation is a viable option and involves the addition of a chemical agent (i.e., ferric sulfate and chloride) to agglomerate the small algal cells to form larger and more settleable and filterable bulks [154]. Sonication can also be used to harvest or extract algal contents, particularly lipids, for biodiesel production [159]. Additionally, sonication can destroy the intact cells and move them to the bottom of the reactor for easier extraction.

The choice between different harvesting methods relies on multiple variables determined by the engineer or designer as well as the parameters that must be followed. For example, in most processes, the cost is often an important factor. As flocculation requires the continuous, simultaneous injection of the chemical agent with the wastewater feed, the cost is relatively high. Similarly, sonication and centrifugation require complex technologies and higher capital costs for higher flow rates [157]. However, natural precipitation and floatation require little to no interference (aside from the use of pumps for aeration), which is less costly. Filtration is also a noticeably faster method than precipitation. Other relevant factors in the decision-making process include mechanical wear issues, energy requirements, and space occupation. 
Table 9. Typical Techniques used in Harvesting of Microalgae.

\begin{tabular}{|c|c|c|c|}
\hline Harvesting Method & Description and Principle & $\begin{array}{c}\text { Relative Cost of } \\
\text { Harvesting Method }\end{array}$ & Refs. \\
\hline Filtration & $\begin{array}{l}\text { Large enough algae can be separated from water by basic } \\
\text { filtration, while smaller ones might require ultrafiltration }\end{array}$ & Medium & [160] \\
\hline Centrifugation & $\begin{array}{l}\text { Mechanical separation of suspended solids according to } \\
\text { their masses and densities by centrifugal force }\end{array}$ & High & [161-163] \\
\hline Floatation & $\begin{array}{l}\text { Aeration of the tank from an entrance below causes air } \\
\text { bubbles to trap and lift the microalgae cells }\end{array}$ & Low & [161] \\
\hline Flocculation & $\begin{array}{l}\text { The addition of a flocculants chemical to form larger algae } \\
\text { clusters can be easily removed by physical means }\end{array}$ & High & {$[78,161,164,165]$} \\
\hline Sonication & $\begin{array}{l}\text { The application of sound energy to disrupt and destroy the } \\
\text { algal cells, leading to the precipitation of their content }\end{array}$ & High & {$[166,167]$} \\
\hline Precipitation & $\begin{array}{l}\text { The natural process of self-precipitation for many large } \\
\text { algae without the need for interference given enough time }\end{array}$ & Low & - \\
\hline
\end{tabular}

Different algae species can be best suited to various forms of fuel due to the diversity in the composition of different algal cells [168]. Algae can be cultivated in a multitude of mediums, including sewage and salt water, and do not require fertile ground or food crops. Cultivation also requires less energy than the algae provide. As such, green microorganisms are a more efficient and environmentally friendly alternative to oil-based fuels. Additionally, algae are among the fastest-growing plant on the planet, with oil accounting for approximately half their weight. The lipid oil may potentially be used as an alternative fuel, especially in the transportation sector [143].

Following algae dewatering, the cell content is typically extracted before further conversion with lipids as the most useful source for biodiesel production. Menegazzo and Fonseca [169], and Vasistha et al. [170] explain the process of lipid extraction in detail along with the process selection options. To summarize, the most common methods of lipid extraction (i.e., cell disruption) are:

1. Direct Chemical Method: Using a mixture solution of chloroform, methanol, and water to effectively isolate (polar and non-polar) lipids in a process called the Folch method [171], the Bligh and Dyer method [172] or a combination of the two.

2. Enzymatic Method: Biological cell disruption through the available and effective enzymes, occurs by the degradation of certain chemical bonds in the cell walls by enzymes such as cellulase, autolysin, and xylanase [173,174].

3. Sonication Method: The cell walls are destroyed by the cavitation caused by the collapse of microbubbles that results from the ultrasonic waves $[159,175,176]$. This method can also be used as a pre-treatment before lipid extraction [169].

4. Microwave-Assisted Method: This method relies on the application of electromagnetic radiation to impose heat (in the range of $0.3-300 \mathrm{GHz}$ ) causing the cell walls to be disrupted, releasing lipids [177-179].

5. Osmotic Shock Method: This method is based on the concept of osmotic pressure with the equilibrium then established between the cells and the medium surrounding them. A sudden large change in the salt concentration in the medium causes the cells to either contract or burst depending on whether the change is increasing or decreasing, respectively, and the lipid is then released $[180,181]$.

6. Physical Extraction Method(s): The application of shear force and direct damage by collision or friction is a viable option to non-selectively destroy cell walls and release their content. Examples of physical extractions include using a French press [182] or a ball mill [183]. 


\section{Potential of Algal Biomass Processing}

The conversion process of algal biomass to biofuels has three primary routes: thermochemical, biochemical, or direct chemical means. Thermochemical conversion relies on high temperatures and pressure to convert the extracted algal cell contents into small monomers that make up the components of biofuel. This process includes the hydrothermal liquefaction process (HTL), a reaction that typically occurs in the pressure and temperature range between 4 and $35 \mathrm{MPa}$ and $200-450{ }^{\circ} \mathrm{C}$, respectively [184-186]. In the HTL process, lipids, carbohydrates, and proteins are degraded and repolymerized to produce biodiesel (phenols, aromatics, and fatty acids) [184-186]. Cui et al. [187] successfully liquefied the microalgae species Galidieria sulphuraria and obtained a bio-oil yield of $96 \% \mathrm{wt} \%$ using glycerol as a co-solvent at a temperature of $350{ }^{\circ} \mathrm{C}$.

Gasification is another conversion route conducted at high temperatures up to $1300{ }^{\circ} \mathrm{C}$ to produce syngas [188]. This process is comprised of several reactions, including the pyrolysis of $\mathrm{C}_{\mathrm{x}} \mathrm{H}_{\mathrm{y}} \mathrm{O}_{\mathrm{z}}$, oxidation of char, Reverse Boudouard reaction, methanation, watergas shift reaction, and steam reforming [188]. Raheem et al. [189] found that the ratio between $\mathrm{H}_{2}$ and $\mathrm{CO} / \mathrm{CO}_{2}$ is controllable and the use of $\mathrm{CaO}$ catalyst from eggshell waste can nearly double the hydrogen yield with the opposite effect on carbon monoxide and carbon dioxide in the gasification of Arthrospira platensi at a catalyst loading rate of $50 \mathrm{wt} \%$.

The last thermochemical type is the pyrolysis conversion process, which relies on intermediate temperatures $\left(400-800{ }^{\circ} \mathrm{C}\right)$ in the total absence of oxygen $[190,191]$. This process yields a variety of products including both liquid and gaseous. The most important parameters for determining the products are the temperature, time, and heating rate. The pyrolysis process is classified based on the heating rate as slow, intermediate, or fast pyrolysis. Hu et al. [192] pyrolyzed a Chlorella vulgaris biomass to yield $91.1 \mathrm{wt} \%$ biofuel at $900{ }^{\circ} \mathrm{C}$. In contrast, microwave-induced pyrolysis (MIP) with Scenedesmus almeriensis produced a bio-oil yield of 22-23 wt \% and a maximum gas yield of $57 \mathrm{wt} \%$ [193].

The second conversion process, biochemical conversion of microalgae, relies on the fermentation of bacteria that feeds on algal cell content to produce biofuels, including acetone, butanol, ethanol (ABE), and hydrogen. Efremenko et al. [194] conducted anaerobic ABE fermentation on multiple algal strains (Arthrospira, Nannochloropsis, Dunaliella, Galdieria, Chlorella, Cosmarium, Nostoc) with the help of the bacterium Clostridium acetobutylicum. The results exemplified a maximum yield of butanol and ethanol of $117 \%$ and $35 \%$, with a hydrogen production of $8.5 \mathrm{mmol} / \mathrm{L} /$ day at a temperature of $37^{\circ} \mathrm{C}$ for one day [194]. Hythane (Hydrogen + Methane) was also able to be produced through a two-stage fermentation process in which each of the components is generated during one stage $[195,196]$.

The third conversion process, direct chemical conversion of lipids to biodiesel, occurs through the reaction of lipids [197-199]. When alcohol is introduced, it breaks down the lipids into fatty esters and glycerol as a side product [197-199]. The process can also be combined with the previously discussed methods for a greater economical approach and higher yields [200-202]. Other improvements to the chemical conversion process include pre-treatment options [203,204] and the transesterification of mixed microbial cultures [205].

\section{Algae Biomass and Biofuel Production}

Increasingly, algal biomass is used to produce commercially competitive biofuels. Green technology aids in the production of biofuels, reduces carbon emissions, and sequesters $\mathrm{CO}_{2}$ in the algae cultivation stage. Algae is also an appealing biofuel source because of its relatively fast growth rate [128] as well as its ability to grow in a variety of mediums, including sewage water and saltwater, without the need for fertile soil or crops [143]. Additionally, algal biomass can be converted into biofuels using thermochemical, biochemical, or direct chemical methods. High pressure $(\mathrm{P})$ and high temperatures $(\mathrm{T})$ are used in HTL, a mild form of thermochemical conversion to help initiate the hydrolysis of large components of the algae such as proteins, carbohydrates, and lipids into smaller monomers. Thereafter, the monomers are decomposed into smaller compounds that reorganize to form the biofuel constituents (i.e., aromatics, phenols, and fatty acids) [184-186]. 
Typically, the end-product is in liquid form because the conversion process is carried out at a low $\mathrm{P}$ and $\mathrm{T}$ of $4-35 \mathrm{MPa}$ and $200-450{ }^{\circ} \mathrm{C}$, respectively, inside the liquid medium (as a bio-oil).

The HTL is a dependable conversion method with a bio-oil yield (BoY) of more than $50 \%$ by weight. For example, He et al. [42] conducted HTL on Nannochloropsis sp. and Sargassum sp. with BoY values of $54.11 \mathrm{wt} \%$ and $9.49 \mathrm{wt} \%$, respectively. Moreover, water is the most common liquid medium for HTL, though other liquids such as methanol, ethanol, isopropanol, and glycerol are viable options [187,206,207]. Yang et al. [208] found that the use of acid catalysts increased the bio-oil formation and had a noticeable impact on the product's H/C ratio. Similarly, Zhu et al. [85] demonstrated how HTL units can be fed mixed feeds, focusing on the synergistic effects of microalgae (Chlorella sp. and Tetraselmis sp.) and wood (Pine and C\&D). When compared to pure feeds, liquefaction blends produced higher yields of bio-oil (40-45\%).

Conversely, gasification is the most extreme form of thermochemical conversion. The process involves the conversion of biomass into biogas at high temperatures $\left(800-1200^{\circ} \mathrm{C}\right)$ in the presence of a gasifying agent. The components of the gasification process are in gas form due to the extreme conditions required for the process (e.g., syngas and methane). Gasification can be performed at lower temperatures; however, the end-product will be affected. Hanchate et al. [209] classified various types of reactors used for gasification according to the reaction conditions, gasifying agent, and mode of operation. Similarly, Raheem et al. [188] investigated the mechanisms of gasification, which are summarized by the set of reactions outlined in Equations (1)-(7).

$$
\mathrm{C}_{\mathrm{x}} \mathrm{H}_{\mathrm{y}} \mathrm{O}_{\mathrm{z}} \rightarrow \text { Syngas }+ \text { biochar }+ \text { tar }+ \text { steam }
$$

where $\mathrm{C}_{\mathrm{x}} \mathrm{H}_{\mathrm{y}} \mathrm{O}_{\mathrm{z}}$ represents the input hydrocarbon to the system, syngas represents the composition of $\left(\mathrm{H}, \mathrm{CO}, \mathrm{CO}_{2}, \mathrm{CH}\right.$ and $\left.\mathrm{C}_{n} \mathrm{H}_{m}\right)$, biochar represents the charcoal produced after biomass pyrolysis, and tar represents a black viscous liquid of hydrocarbon.

$$
\begin{gathered}
\mathrm{C}+\frac{1}{2} \mathrm{O}_{2} \rightarrow \mathrm{CO} \\
\mathrm{C}+\mathrm{O}_{2} \rightarrow \mathrm{CO}_{2} \\
\mathrm{C}+\mathrm{CO}_{2} \Leftrightarrow 2 \mathrm{CO} \\
\mathrm{C}+2 \mathrm{H}_{2} \Leftrightarrow \mathrm{CH}_{4} \\
\mathrm{CO}+\mathrm{H}_{2} \mathrm{O} \Leftrightarrow \mathrm{H}_{2}+\mathrm{CO}_{2} \\
\mathrm{CH}_{4}+\mathrm{H}_{2} \mathrm{O} \Leftrightarrow \mathrm{CO}+3 \mathrm{H}_{2}
\end{gathered}
$$

Soares et al. [210] demonstrated the gasification of mixed microalgae culture in a commercial downdraft gasifier. The process produced syngas up to $2.8 \mathrm{Nm}^{3} / \mathrm{kg}$ with a dry biomass of $0.23 \mathrm{ER}$, and hydrogen and carbon monoxide fractions of $11.9 \%$ and $19.5 \%$, respectively (i.e., the recommended amount for production) [210]. In contrast, Raheem et al. [188] used COD to investigate the effect of a $\mathrm{ZnO}-\mathrm{Ni}-\mathrm{CaO}$ catalyst on Chlorella vulgaris gasification as well as to determine the optimum parameters. The fraction and yield of hydrogen gas were $48.95 \%$ and $18.77 \mathrm{~mol} / \mathrm{kg}$ biomass, respectively, at $851{ }^{\circ} \mathrm{C}, 16.4 \mathrm{wt} \%$ catalyst loading rate, and $28.8 \mathrm{~min}$ reaction time [188]. Other catalysts that have been shown to affect gasification are $\mathrm{NaOH}$ [211] eggshell waste (CaO) [189], and zeolites [91].

Pyrolysis, a thermochemical process, is situated in the middle of the two previously discussed processes. Pyrolysis is versatile and applicable to sewage wastewater [212], kitchen wastewater [213], and can be aided by the use of microwaves [194,214]. Yang et al. [190] and Lee et al. [191] summarized the principles of pyrolysis and recent advances. Pyrolysis of microalgae is the decomposition of microorganism contents caused by a lack of oxygen, which is classified according to the heating rate (i.e., slow, intermediate, and 
fast) [190]. This process is typically carried out between the temperature range of 400 and $900{ }^{\circ} \mathrm{C}$ [190]. As this process is halfway between HTL and gasification, the mechanism and products are a mix of both solid and gas (unless extreme low or high temperatures are used). The use of a high temperature will make the outcome closer to HTL or gasification. For example, Hu et al. [192] conducted a fast analysis at $900^{\circ} \mathrm{C}$, which produced $91.09 \mathrm{wt} \%$ biofuel and the highest $\mathrm{CO}$ and $\mathrm{H}_{2}$ emissions in the temperature range of $800-900{ }^{\circ} \mathrm{C}$. Pyrolysis, similarly to thermochemical processes, can be catalyzed; examples of which include oyster shells $\left(\mathrm{CaCO}_{3}\right)$ [215], $\mathrm{ZnCl}_{2}, \mathrm{SiC}, \mathrm{MgO}$, and activated carbon [216]. Lastly, $\mathrm{Xu}$ et al. [211] combined HTL-gasification processes, which highlighted that it is possible to combine processes. The HTL unit's effluent is sent to the gasification unit for increased energy recovery [211].

Fermentation, a common biochemical conversion technique, is used for turning microalgae into biofuels. Fermentation emphasizes the synergies between bacteria and microalgae. Bacteria break down microalgae constituents such as carbohydrates, lipids, and proteins to produce biofuels (e.g., biogas and alcohols) from which nutrients can be obtained. Then, the constituents are hydrolyzed to yield starch, glucose, glycerol, fatty acids, alcohols, amino acids, and peptides. Efremenko et al. [194] conducted an ABE fermentation on various microalgae strains using the immobilized bacteria Clostridium acetobutylicum. The Nannochloropsis sp. produced up to $8.5 \mathrm{mmol} / \mathrm{L}$ per day of hydrogen, while Arthrospira platensis produced up to $117 \%$ and $35 \%$ butanol and ethanol yields, respectively [194]. Additionally, Ho et al. [217] and Llamas et al. [218] studied the biochemical conversion of Chlorella vulgaris into ethanol and methane.

Hythane, a gas mixture primarily comprised of methane with a small amount of hydrogen, is particularly useful for commercial purposes. Hythane improves engine combustion while lowering $\mathrm{CO}_{2}$ and NOx emissions [219]. The gas mixture is produced using a two-stage anaerobic digestion process in which each component of the blend $\left(\mathrm{H}_{2} / \mathrm{CH}_{4}\right)$ is separately fermented before being blended at high production rates $[195,196]$. Pre-treatment methods can further improve the fermentation process [196]. Low-cost biological pre-treatment options such as a fungal pre-treatment provide fermentation efficiencies up to $92 \%$ from Kappaphycus alvarezii [220]. Chemical pre-treatments can also be used [220]. Additionally, physical pre-treatments such as ultrasound and microwave are useful [221].

Fermentation can be combined with other processes in large-scale integrated designs to maximize output and reduce costs. Examples of combined processes include integrating microalgae fermentation with $\mathrm{HTL}$ [83], $\mathrm{CO}_{2}$ fixation, and pyrolysis [222,223]. El-Dalatony et al. [202], and Sivaramakrishnan and Incharoensakdi [200] proposed an integrated chemical transesterification process for high bioethanol and high alcohol yields. According to Chandra et al. [224], culture operating conditions such as $\mathrm{pH}$, temperature, cultivation period, and the presence of supplements significantly impact the process performance.

Transesterification chemically converts microalgae into biofuels (specifical biodiesel) [197-199]. The most important components of the microalgae biomass for transesterification are lipids esterified by alcohol to produce biodiesel (Fatty Acid Alkyl Esters), as well as other side products (i.e., glycerol) created by a reversible and catalytic reaction (citation needed). Sivaramakrishnan and Incharoensakdi [200] exemplified how the transesterification of Scenedesmus sp. resulted in a methyl ester yield up to $92 \%$. This emphasizes the practicability of biodiesel transesterification as well as the importance of process parameters (i.e., temperature, catalyst weight ratio, and reaction time). Further, methanol is the most commonly used alcohol, though alkali catalysts $(\mathrm{NaOH})$ [225], enzymatic catalysts (lipase) [200], acidic catalysts (sulfuric acid) [221,226], and iron nanoparticles [227] have been used as catalysts for the chemical reaction. To produce biofuels from Nannochloropsis salina through transesterification, Hess and Quinn [228] compared acidic catalysts with the sole use of methanol at supercritical conditions. The results indicated that the two latter methods produced 0.28 and $0.32 \mathrm{~g} / \mathrm{g}$ microalgae biofuel, respectively, with a FAME recovery efficiency of $89 \%$ and $100 \%$, respectively. 
As commercial-scale chemical reactions require a constant supply of alcohol-a prohibitive cost-it is common to seek out more cost-effective alternatives. For example, Ashokkumar et al. [212] investigated how to increase the cost efficiency of the process by cultivating microalgae using municipal sewage (Chlorella sp. and Sargassum sp.). The process was integrated into a combined transesterification-pyrolysis method with a maximum biodiesel (FAME) yield by the researchers. The use of wastelands [229] and landfillgenerated wastewater [230] are two additional efforts to increase the economic feasibility of the process. As such, the transesterification of microalgae mixed with other microbial communities (i.e., bacteria and viruses) resulted in a product with a FAME content of $485(w / w)[205]$

\section{Conclusions}

The treatment of PW can help alleviate the scarcity of water and enhance the recovery of sustainable resources from oil and gas fields. After further processing is undertaken, algae technology can remediate the toxic effect of pollutants present in PW and utilize nutrient supplements and beneficial chemicals to make water available for additional uses. The produced biomass can also be employed for the production of biofuel. Thus, algaetreated PW provides significant advantages for water availability and culture optimization.

Given that, the current analysis detailed the possibilities of producing algae with PW as a micronutrient and freshwater substitute. Although research shows that salinity and nutrients in PW promote algal development, pre-treatment, dilatation of PW, and added nutrients are frequently required. The important treatment phases, detailed in this study, are critical for promoting algae cultivation in PW. In addition, the importance of promoting halotolerant and marine algae species is highlighted. Yet, there is still much to be learned and difficulties that should be explored, including algae and PW processing upstream and downstream. Our recommendation is for research to focus on the performance of pre-adapted algae in PW, especially regarding removal, the effect of salinity and the fatty acid profile, lipid production, and biomass generation. As much of the previous work has not provided clear conclusions, we cannot make a definitive conclusion about the viability of large-scale algal processes for the treatment of PW. However, algal technology has the potential to be a successful candidate for the biological treatment of PW. As such, we highly recommend further research on this promising field, which not only offers PW for reuse but also provides a great opportunity to grow algae for biofuel via the three common routes and other added-value products.

Author Contributions: Conceptualization, M.A., F.A.; methodology, M.A., F.A.; validation, M.A., F.A.; formal analysis, M.K., M.S.N. and Y.S.; investigation, M.A., F.A. and Y.S.; writing-original draft preparation, M.A., F.A.; writing-review and editing, M.K., M.S.N. and Y.S.; visualization, M.K.; M.S.N. and Y.S.; supervision F.A. All authors have read and agreed to the published version of the manuscript.

Funding: This paper was made possible by the financial support provided through the internal collaborative grant number QUCG-CENG-21/22-3 funded by Qatar university.

Institutional Review Board Statement: Not applicable.

Informed Consent Statement: Not applicable.

Data Availability Statement: The data will be available upon request.

Conflicts of Interest: The authors declare no conflict of interest.

\section{References}

1. Rahman, A.; Agrawal, S.; Nawaz, T.; Pan, S.; Selvaratnamm, T. A review of algae-based produced water treatment for biomass and biofuel production. Water 2020, 12, 2351. [CrossRef]

2. Lin, L.; Jiang, W.; Chen, L.; Xu, P.; Wang, H. Treatment of produced water with photocatalysis: Recent advances, affecting factors and future research prospects. Catalysts 2020, 10, 924. [CrossRef] 
3. Liu, Y.; Li, Y.; Lu, H.; Pan, Z.; Dai, P.; Sun, G.; Yang, Q. A full-scale process for produced water treatment on offshore oilfield: Reduction of organic pollutants dominated by hydrocarbons. J. Clean. Prod. 2021, 296, 126511. [CrossRef]

4. Fakhru'L-Razi, A.; Pendashteh, A.; Abdullah, L.C.; Biak, D.R.A.; Madaeni, S.S.; Abidin, Z.Z. Review of technologies for oil and gas produced water treatment. J. Hazard. Mater. 2009, 170, 530-551. [CrossRef] [PubMed]

5. Duraisamy, R.T.; Beni, A.H.; Henni, A. State of the art treatment of produced water. In Water Treatement; InTech Open: London, UK, 2013; pp. 199-222.

6. Jiménez, S.; Micó, M.M.; Arnaldos, M.; Medina, F.; Contreras, S. State of the art of produced water treatment. Chemosphere 2018, 192, 186-208. [CrossRef]

7. Zhang, Z.; Du, X.; Carlson, K.H.; Robbins, C.A.; Tong, T. Effective treatment of shale oil and gas produced water by membrane distillation coupled with precipitative softening and walnut shell filtration. Desalination 2019, 454, 82-90. [CrossRef]

8. Al-Ghouti, M.A.; Al-Kaabi, M.A.; Ashfaq, M.Y.; Da'na, D.A. Produced water characteristics, treatment and reuse: A review. J. Water Process Eng. 2019, 28, 222-239. [CrossRef]

9. Ali, A.; Quist-Jensen, C.A.; Drioli, E.; Macedonio, F. Evaluation of integrated microfiltration and membrane distillation/crystallization processes for produced water treatment. Desalination 2018, 434, 161-168. [CrossRef]

10. Jiang, W.; Lin, L.; Xu, X.; Cheng, X.; Zhang, Y.; Hall, R.; Xu, P. A Critical Review of Analytical Methods for Comprehensive Characterization of Produced Water. Water 2021, 13, 183. [CrossRef]

11. Riley, S.M.; Oliveira, J.; Regnery, J.; Cath, T.Y. Hybrid membrane bio-systems for sustainable treatment of oil and gas produced water and fracturing flowback water. Sep. Purif. Technol. 2016, 171, 297-311. [CrossRef]

12. Freedman, D.E.; Riley, S.M.; Jones, Z.L.; Rosenblum, J.S.; Sharp, J.O.; Spear, J.R.; Cath, T.Y. Biologically active filtration for fracturing flowback and produced water treatment. J. Water Process Eng. 2017, 18, 29-40. [CrossRef]

13. Kiss, Z.L.; Kovacs, I.; Veréb, G.; Hodúr, C.; László, Z. Treatment of model oily produced water by combined pre-ozonationmicrofiltration process. Desalin. Water Treat. 2016, 57, 23225-23231. [CrossRef]

14. Lu, M.; Zhang, Z.; Yu, W.; Zhu, W. Biological treatment of oilfield-produced water: A field pilot study. Int. Biodeterior. Biodegrad. 2009, 63, 316-321. [CrossRef]

15. Camarillo, M.K. and Stringfellow, W.T. Biological treatment of oil and gas produced water: A review and meta-analysis. Clean Technol. Environ. Policy 2018, 20, 1127-1146. [CrossRef]

16. Caspeta, L.; Buijs, N.A.; Nielsen, J. The role of biofuels in the future energy supply. Energy Environ. Sci. 2013, 6, 1077-1082. [CrossRef]

17. De-Luca, R.; Bezzo, F.; Béchet, Q.; Bernard, O. Exploiting meteorological forecasts for the optimal operation of algal ponds. J. Process Control 2017, 55, 55-65. [CrossRef]

18. Graham, E.J.S.; Dean, C.A.; Yoshida, T.M.; Twary, S.N.; Teshima, M.; Alvarez, M.A.; Zidenga, T.; Heikoop, J.; Perkins, G.; Rahn, T.A.; et al. Oil and gas produced water as a growth medium for microalgae cultivation: A review and feasibility analysis. Algal Res. 2017, 24, 492-504. [CrossRef]

19. Atoufi, H.D.; Lampert, D.J. Impacts of oil and gas production on contaminant levels in sediments. Curr. Pollut. Rep. 2020, 6, 43-53. [CrossRef]

20. Igunnu, E.T.; Chen, G.Z. Produced water treatment technologies. Int. J. Low-Carbon Technol. 2014, 9, 157-177. [CrossRef]

21. Eia, U. International Energy Outlook; US Energy Information Administration: Washington, DC, USA, 2011.

22. Campos, J.C.; Borges, R.M.H.; Oliveira Filho, A.M.D.; Nobrega, R.; Sant'Anna, G., Jr. Oilfield wastewater treatment by combined microfiltration and biological processes. Water Res. 2002, 36, 95-104. [CrossRef]

23. Nouvelles, I.E. Water in Fuel Production-Oil Production and Refining; Techincal Report. 2011. Available online: http://www. ifpenergiesnouvelles.com/content (accessed on 19 November 2021).

24. Dórea, H.S.; Bispo, J.R.; Aragão, K.A.; Cunha, B.B.; Navickiene, S.; Alves, J.P.; Romão, L.P.; Garcia, C.A. Analysis of BTEX, PAHs and metals in the oilfield produced water in the State of Sergipe, Brazil. Microchem. J. 2007, 85, 234-238. [CrossRef]

25. Baca, S.R.; Kupfer, A.; McLain, S. Analysis of the Relationship between Current Regulatory and Legal Frameworks and the "Produced Water Act"; NM WRRI Technical Completion Report No. 396; New Mexico Water Resources Research Institute: Las Cruces, NM, USA, 2021

26. Clark, C.E.; Veil, J.A. Produced Water Volumes and Management Practices in the United States; Argonne National Lab. (ANL): Argonne, IL, USA, 2009.

27. Winckelmann, D.; Bleeke, F.; Thomas, B.; Elle, C.; Klöck, G. Open pond cultures of indigenous algae grown on non-arable land in an arid desert using wastewater. Int. Aquat. Res. 2015, 7, 221-233. [CrossRef]

28. Operation, N.G. Qatar Petroleum. State of Qatar. In Proceedings of the International Petroleum Technology Conference, Doha, Qatar, 19-22 January 2014.

29. Al Kaabi, M.A. Enhancing Produced Water Quality Using Modified Activated Carbon; Qatar University: Doha, Qatar, 2016.

30. Zemlick, K.; Kalhor, E.; Thomson, B.M.; Chermak, J.M.; Graham, E.J.S.; Tidwell, V.C. Mapping the energy footprint of produced water management in New Mexico. Environ. Res. Lett. 2018, 13, 024008. [CrossRef]

31. Bhadja, P.; Kundu, R. Status of the Seawater Quality at Few Industrially Important Coasts of Gujarat (India) off Arabian Sea; NISCAIR-CSIR: New Delhi, India, 2012.

32. Tibbetts, P.; Buchanan, I.; Gawel, L.; Large, R. A comprehensive determination of produced water composition. In Produced Water; Springer: Berlin/Heidelberg, Germany, 1992; pp. 97-112. 
33. Nasiri, M.; Jafari, I. Produced water from oil-gas plants: A short review on challenges and opportunities. Period. Polytech. Chem. Eng. 2017, 61, 73-81. [CrossRef]

34. Fillo, J.P.; Koraido, S.M.; Evans, J.M. Sources, characteristics, and management of produced waters from natural gas production and storage operations. In Produced Water: Technological/Environmental Issues and Solutions; Ray, J.P., Engelhardt, F.R., Eds.; Springer: Boston, MA, USA, 1992; pp. 151-161.

35. Tawabini, B.S.; Plakas, K.V.; Karabelas, A.J. A pilot study of BTEX removal from highly saline water by an advanced electrochemical process. J. Water Process Eng. 2020, 37, 101427. [CrossRef]

36. Sheikholeslami, Z.; Kebria, D.Y.; Qaderi, F. Investigation of photocatalytic degradation of BTEX in produced water using $\gamma$-Fe 2 $\mathrm{O}_{3}$ nanoparticle. J. Therm. Anal. Calorim. 2019, 135, 1617-1627. [CrossRef]

37. Zhai, J.; Ma, H.; Liao, J.; Rahaman, M.; Yang, Z.; Chen, Z. Comparison of Fenton, ultraviolet-Fenton and ultrasonic-Fenton processes on organics and colour removal from pre-treated natural gas produced water. Int. J. Environ. Sci. Technol. 2018, 15, 2411-2422. [CrossRef]

38. Jiménez, S.; Andreozzi, M.; Mico, M.M.; Alvarez, M.G.; Contreras, S. Produced water treatment by advanced oxidation processes. Sci. Total Environ. 2019, 666, 12-21. [CrossRef]

39. Jiménez, S.; Mico, M.M.; Arnaldos, M.; Ferrero, E.; Malfeito, J.J.; Medina, F.; Contreras, S. Integrated processes for produced water polishing: Enhanced flotation/sedimentation combined with advanced oxidation processes. Chemosphere 2017, 168, 309-317. [CrossRef] [PubMed]

40. Sheikholeslami, Z.; Kebria, D.Y.; Qaderi, F. Nanoparticle for degradation of BTEX in produced water; an experimental procedure. J. Mol. Liq. 2018, 264, 476-482. [CrossRef]

41. da Silva Almeida, F.B.P.; Esquerre, K.; Soletti, J.I.; De Farias Silva, C.E. Coalescence process to treat produced water: An updated overview and environmental outlook. Environ. Sci. Pollut. Res. 2019, 26, 1-21. [CrossRef] [PubMed]

42. He, S.; Zhao, M.; Wang, J.; Cheng, Z.; Yan, B.; Chen, G. Hydrothermal liquefaction of low-lipid algae Nannochloropsis sand Sargassum sp.: Effect of feedstock composition and temperature. Sci. Total Environ. 2020, 712, 135677. [CrossRef] [PubMed]

43. He, M.; Chen, W.J.; Tian, L.; Shao, B.; Lin, Y. Plant-microbial synergism: An effective approach for the remediation of shale-gas fracturing flowback and produced water. J. Hazard. Mater. 2019, 363, 170-178. [CrossRef]

44. Wang, H.; Lu, L.; Chen, X.; Bian, Y.; Ren, Z.J. Geochemical and microbial characterizations of flowback and produced water in three shale oil and gas plays in the central and western United States. Water Res. 2019, 164, 114942. [CrossRef] [PubMed]

45. Kardena, E.; Hidayat, S.; Nora, S.; Helmy, Q. Biological treatment of synthetic oilfield-produced water in activated sludge using a consortium of endogenous bacteria isolated from a tropical area. J. Pet. Environ. Biotechnol. 2017, 8, 3. [CrossRef]

46. Acharya, S.M.; Chakraborty, R.; Tringe, S.G. Emerging trends in biological treatment of wastewater from unconventional oil and gas extraction. Front. Microbiol. 2020, 11, 569019. [CrossRef]

47. Abdel-Raouf, N.; Al-Homaidan, A.; Ibraheem, I. Microalgae and wastewater treatment. Saudi J. Biol. Sci. 2012, 19, 257-275. [CrossRef]

48. Arbib, Z.; Ruiz, J.; Álvarez-Díaz, P.; Garrido-Perez, C.; Perales, J.A. Capability of different microalgae species for phytoremediation processes: Wastewater tertiary treatment, $\mathrm{CO}_{2}$ bio-fixation and low cost biofuels production. Water Res. 2014, 49, 465-474. [CrossRef]

49. Åkerström, A.M.; Mortensen, L.M.; Rusten, B.; Gislerød, H.R. Biomass production and nutrient removal by Chlorella sas affected by sludge liquor concentration. J. Environ. Manag. 2014, 144, 118-124. [CrossRef]

50. Mohamad, S.; Fares, A.; Judd, S.; Bhosale, R.; Kumar, A.; Gosh, U.; Khreisheh, M. Advanced Wastewater Treatment Using Microalgae: Effect of Temperature on Removal of Nutrients and Organic Carbon. In Proceedings of the 7th International Conference on Environment and Industrial Innovation, Kuala Lampur, Malaysia, 28-30 April 2017; Volume 67, p. 012032.

51. Gao, F.; Peng, Y.-Y.; Li, C.; Yang, G.-J.; Deng, Y.-B.; Xue, B.; Guo, Y.-M. Simultaneous nutrient removal and biomass/lipid production by Chlorella sin seafood processing wastewater. Sci. Total Environ. 2018, 640-641, 943-953. [CrossRef]

52. Almomani, F.; Judd, S.; Shurair, M. Potential use of mixed indigenous microalgae for carbon dioxide bio-fixation and advanced wastewater treatment. In 2017 Spring Meeting and 13th Global Congress on Process Safety; AIChE: New York, NY, USA, 2017.

53. Sivakumar, G.; Xu, J.; Thompson, R.W.; Yang, Y.; Randol-Smith, P.; Weathers, P.J. Integrated green algal technology for bioremediation and biofuel. Bioresour. Technol. 2012, 107, 1-9. [CrossRef]

54. Davis, R.E.; Fishman, D.B.; Frank, E.D.; Johnson, M.C.; Jones, S.B.; Kinchin, C.M.; Skaggs, R.L.; Venteris, E.R.; Wigmosta, M.S. Integrated evaluation of cost, emissions, and resource potential for algal biofuels at the national scale. Environ. Sci. Technol. 2014, 48, 6035-6042. [CrossRef] [PubMed]

55. Ventura, J.-R.S.; Yang, B.; Lee, Y.-W.; Lee, K.; Jahng, D. Life cycle analyses of $\mathrm{CO}_{2}$, energy, and cost for four different routes of microalgal bioenergy conversion. Bioresour. Technol. 2013, 137, 302-310. [CrossRef]

56. Kang, Z.; Kim, B.-H.; Ramanan, R.; Choi, J.-E.; Yang, J.-W.; Oh, H.-M.; Kim, H.-S. A cost analysis of microalgal biomass and biodiesel production in open raceways treating municipal wastewater and under optimum light wavelength. J. Microbiol. BioTechnol. 2015, 25, 109-118. [CrossRef]

57. Judd, S.; Al Momani, F.; Znad, H.; Al Ketife, A. The cost benefit of algal technology for combined $\mathrm{CO}_{2}$ mitigation and nutrient abatement. Renew. Sustain. Energy Rev. 2017, 71 (Suppl. C), 379-387. [CrossRef]

58. Godfrey, V. Production of Biodiesel from Oleaginous Organisms Using Underutilized Wastewaters. Ph.D. Thesis, Utah State University, Logan, UT, USA, 2012. 
59. Ranjbar, S.; Quaranta, J.; Tehrani, R.; Van Aken, B. Algae-based treatment of hydraulic fracturing produced water: Metal removal and biodiesel production by the halophilic microalgae Dunaliella salina. In Bioremediation and Sustainable Environmental Technologies. In Proceedings of the Third International Symposium on Bioremediation and Sustainable Environmental Technologies, Miami, FL, USA, 18-21 May 2015; Springer: Berlin/Heidelberg, Germany, 2015.

60. Neal, J.N.; Sullivan, E.J.; Dean, C.A.; Steichen, S.A. Recycling Produced Water for Algal Cultivation for Biofuels; Los Alamos National Lab. (LANL): Los Alamos, NL, USA, 2012.

61. Hopkins, T.C.; Graham, E.J.S.; Schuler, A.J. Biomass and lipid productivity of Dunaliella tertiolecta in a produced water-based medium over a range of salinities. J. Appl. Phycol. 2019, 31, 3349-3358. [CrossRef]

62. Singh, G.; Patidar, S. Microalgae harvesting techniques: A review. J. Environ. Manag. 2018, 217, 499-508. [CrossRef]

63. Talebi, A.F.; Dastgheib, S.M.M.; Tirandaz, H.; Ghafari, A.; Alaie, E.; Tabatabaei, M. Enhanced algal-based treatment of petroleum produced water and biodiesel production. RSC Adv. 2016, 6, 47001-47009. [CrossRef]

64. Parsy, A.; Sambusiti, C.; Baldoni-Andrey, P.; Elan, T.; Périé, F. Cultivation of Nannochloropsis oculata in saline oil \& gas wastewater supplemented with anaerobic digestion effluent as nutrient source. Algal Res. 2020, 50, 101966.

65. Takáčová, A.; Smolinská, M.; Semerád, M.; Matúš, P. Degradation of btex by microalgae Parachlorella kessleri. Petrol. Coal 2015, 57, 101-107.

66. Abdelsalam, E.; Kafiah, F.; Tawalbeh, M.; Almomani, F.; Azzam, A.; Alzoubi, I.; Alkasrawi, M. Performance analysis of hybrid solar chimney-power plant for power production and seawater desalination: A sustainable approach. Int. J. Energy Res. 2021, 45, 17327-17341. [CrossRef]

67. Das, S.K.; Sathish, A.; Stanley, J. Production of biofuel and bioplastic from Chlorella Pyrenoidosa. Mater. Today Proc. 2018, 5, 16774-16781. [CrossRef]

68. Wilson, M.H.; Shea, A.; Groppo, J.; Crofcheck, C.; Quiroz, D.; Quinn, J.C.; Crocker, M. Algae-based beneficial re-use of carbon emissions using a novel photobioreactor: A techno-economic and life cycle analysis. BioEnergy Res. 2020, 14, 292-302. [CrossRef]

69. Rafiee, P.; Ebrahimi, S.; Hosseini, M.; Tong, Y.W. Characterization of soluble algal products (SAPs) after electrocoagulation of a mixed algal culture. Biotechnol. Rep. 2020, 25, e00433. [CrossRef]

70. Hopkins, T.C.; Graham, E.J.S.; Schwilling, J.; Ingram, S.; Gómez, S.M.; Schuler, A.J. Effects of salinity and nitrogen source on growth and lipid production for a wild algal polyculture in produced water media. Algal Res. 2019, 38, 101406. [CrossRef]

71. Karatay, S.E.; Dönmez, G. Microbial oil production from thermophile cyanobacteria for biodiesel production. Appl. Energy 2011, 88, 3632-3635. [CrossRef]

72. Das, P.; Abdulquadir, M.; Thaher, M.; Khan, S.; Chaudhary, A.K.; Alghasal, G.; Al-Jabri, H.M.S.J. Microalgal bioremediation of petroleum-derived low salinity and low pH produced water. J. Appl. Phycol. 2019, 31, 435-444. [CrossRef]

73. Liber, J.A.; Bryson, A.E.; Bonito, G.; Du, Z. Harvesting microalgae for food and energy products. Small Methods 2020, 4, 2000349. [CrossRef]

74. Mata, T.M.; Martins, A.A.; Caetano, N.S. Microalgae for biodiesel production and other applications: A review. Renew. Sustain. Energy Rev. 2010, 14, 217-232. [CrossRef]

75. Slade, R.; Bauen, A. Micro-algae cultivation for biofuels: Cost, energy balance, environmental impacts and future prospects. Biomass Bioenergy 2013, 53, 29-38. [CrossRef]

76. Almomani, F.; Bhosale, R.; Khraisheh, M.; Kumar, A.; Almomani, T. Heavy metal ions removal from industrial wastewater using magnetic nanoparticles (MNP). Appl. Surf. Sci. 2020, 506, 144924. [CrossRef]

77. Fuad, N.; Omar, R.; Kamarudin, S.; Harun, R.; Idris, A.; W.A.K.G., W.A. Mass harvesting of marine microalgae using different techniques. Food Bioprod. Process. 2018, 112, 169-184. [CrossRef]

78. Grima, E.M.; Belarbi, E.-H.; Fernández, F.G.A.; Medina, A.R.; Chisti, Y. Recovery of microalgal biomass and metabolites: Process options and economics. Biotechnol. Adv. 2003, 20, 491-515. [CrossRef]

79. Yin, Z.; Zhu, L.; Li, S.; Hu, T.; Chu, R.; Mo, F.; Hu, D.; Liu, C.; Li, B. A comprehensive review on cultivation and harvesting of microalgae for biodiesel production: Environmental pollution control and future directions. Bioresour. Technol. 2020, 301, 122804 [CrossRef] [PubMed]

80. Posada, J.A.; Brentner, L.B.; Ramirez, A.; Patel, M.K. Conceptual design of sustainable integrated microalgae biorefineries: Parametric analysis of energy use, greenhouse gas emissions and techno-economics. Algal Res. 2016, 17, 113-131. [CrossRef]

81. Almomani, F.; Al Ketife, A.; Judd, S.; Shurair, M.; Bhosale, R.R.; Znad, H.; Tawalbeh, M. Impact of $\mathrm{CO}_{2}$ concentration and ambient conditions on microalgal growth and nutrient removal from wastewater by a photobioreactor. Sci. Total Environ. 2019, 662, 662-671. [CrossRef] [PubMed]

82. Xu, Z.; Wang, H.; Cheng, P.; Chang, T.; Chen, P.; Zhou, C.; Ruan, R. Development of integrated culture systems and harvesting methods for improved algal biomass productivity and wastewater resource recovery-A review. Sci. Total Environ. 2020, 746, 141039. [CrossRef]

83. Anto, S.; Mukherjee, S.S.; Muthappa, R.; Mathimani, T.; Deviram, G.; Kumar, S.; Verma, T.N.; Pugazhendhi, A. Algae as green energy reserve: Technological outlook on biofuel production. Chemosphere 2020, 242, 125079. [CrossRef] [PubMed]

84. Pruvost, J.; Goetz, V.; Artu, A.; Das, P.; Al Jabri, H. Thermal modeling and optimization of microalgal biomass production in the harsh desert conditions of State of Qatar. Algal Res. 2019, 38, 101381. [CrossRef]

85. Pittman, J.K.; Dean, A.P.; Osundeko, O. The potential of sustainable algal biofuel production using wastewater resources. Bioresour. Technol. 2011, 102, 17-25. [CrossRef] [PubMed] 
86. Baral, S.S.; Singh, K.; Sharma, P. The potential of sustainable algal biofuel production using $\mathrm{CO}_{2}$ from thermal power plant in India. Renew. Sustain. Energy Rev. 2015, 49, 1061-1074. [CrossRef]

87. Sturm, B.S.; Lamer, S.L. An energy evaluation of coupling nutrient removal from wastewater with algal biomass production. Appl. Energy 2011, 88, 3499-3506. [CrossRef]

88. Li, Y.; Zhou, W.; Hu, B.; Min, M.; Chen, P.; Ruan, R.R. Integration of algae cultivation as biodiesel production feedstock with municipal wastewater treatment: Strains screening and significance evaluation of environmental factors. Bioresour. Technol. 2011, 102, 10861-10867. [CrossRef]

89. Iasimone, F.; Panico, A.; De Felice, V.; Fantasma, F.; Iorizzi, M.; Pirozzi, F. Effect of light intensity and nutrients supply on microalgae cultivated in urban wastewater: Biomass production, lipids accumulation and settleability characteristics. J. Environ. Manag. 2018, 223, 1078-1085. [CrossRef]

90. Ji, M.-K.; Abou-Shanab, R.; Kim, S.-H.; Salama, E.-S.; Lee, S.-H.; Kabra, A.N.; Lee, Y.-S.; Hong, S.; Jeon, B.-H. Cultivation of microalgae species in tertiary municipal wastewater supplemented with $\mathrm{CO}_{2}$ for nutrient removal and biomass production. Ecol. Eng. 2013, 58, 142-148. [CrossRef]

91. Das, P.; Thaher, M.I.; Hakim, M.A.Q.M.A.; Al-Jabri, H.M.S. Sustainable production of toxin free marine microalgae biomass as fish feed in large scale open system in the Qatari desert. Bioresour. Technol. 2015, 192, 97-104. [CrossRef] [PubMed]

92. Vieira de Mendonça, H.; Assemany, P.; Abreu, M.; Couto, E.; Maciel, A.M.; Duarte, R.L.; Barbosa dos Santos, M.G.; Reis, A Microalgae in a global world: New solutions for old problems? Renew. Energy 2021, 165, 842-862. [CrossRef]

93. Al Ghazal, G.; Bounnit, T.; Al Muraikhi, M.; Rasheed, R.; Dalgamouni, T.; Saadaoui, I.; Al Jabri, H. Qatar University culture collection: A source of biodiversity and numerous applications. In Qatar University Life Science Symposium 2016: Biodiversity, Sustainability and Climate Change, with Perspectives from Qatar; Hamad bin Khalifa University Press (HBKU Press): Ar Rayyan, Qatar, 2016.

94. Das, P.; Thaher, M.; AbdulQuadir, M.; Khan, S.; Chaudhary, A.; Al-Jabri, H. Long-term semi-continuous cultivation of a halo-tolerant Tetraselmis susing recycled growth media. Bioresour. Technol. 2019, 276, 35-41. [CrossRef] [PubMed]

95. Das, P.; Quadir, M.A.; Chaudhary, A.K.; Thaher, M.I.; Khan, S.; Alghazal, G.; Al-Jabri, H. Outdoor continuous cultivation of self-settling marine Cyanobacterium chroococcidiopsis sp. Ind. Biotechnol. 2018, 14, 45-53. [CrossRef]

96. Huang, Q.; Jiang, F.; Wang, L.; Yang, C. Design of photobioreactors for mass cultivation of photosynthetic organisms. Engineering 2017, 3, 318-329. [CrossRef]

97. Acién, F.; Molina, E.; Reis, A.; Torzillo, G.; Zittelli, G.; Sepúlveda, C.; Masojídek, J. Photobioreactors for the production of microalgae. In Microalgae-Based Biofuels and Bioproducts; Gonzalez-Fernandez, C., Muñoz, R., Eds.; Woodhead Publishing: Sawston, UK, 2017; pp. 1-44.

98. Weissman, J.C.; Goebel, R.P. Production of Liquid Fuels and Chemicals by Microalgae. Final Subcontract Report; Microbial Products Inc.: Fairfield, CA, USA, 1985.

99. Almomani, F.A. Assessment and modeling of microalgae growth considering the effects of $\mathrm{CO}_{2}$, nutrients, dissolved organic carbon and solar irradiation. J. Environ. Manag. 2019, 247, 738-748. [CrossRef] [PubMed]

100. Almomani, F.; Örmeci, B. Assessment of algae-based wastewater treatment in hot climate region: Treatment performance and kinetics. Process Saf. Environ. Prot. 2020, 141, 140-149. [CrossRef]

101. Znad, H.; Naderi, G.; Ang, H.; Tadé, M. $\mathrm{CO}_{2}$ biomitigation and biofuel production using microalgae: Photobioreactors developments and future directions. Adv. Chem. Eng. 2012, 9, 230-244.

102. Álvarez-Díaz, P.D.; Ruiz, J.; Arbib, Z.; Barragán, J.; Garrido-Pérez, M.C.; Perales, J.A. Freshwater microalgae selection for simultaneous wastewater nutrient removal and lipid production. Algal Res. 2017, 24, 477-485. [CrossRef]

103. Metsoviti, M.N.; Papapolymerou, G.; Karapanagiotidis, I.T.; Katsoulas, N. Effect of light intensity and quality on growth rate and composition of Chlorella vulgaris. Plants 2019, 9, 31. [CrossRef]

104. Gunawan, T.J.; Ikhwan, Y.; Restuhadi, F.; Pato, U. Effect of light Intensity and photoperiod on growth of Chlorella pyrenoidosa and $\mathrm{CO}_{2}$ biofixation. E3S Web Conf. EDP Sci. 2018, 31, 03003. [CrossRef]

105. Richmond, A. Physiological principles and modes of cultivation in mass production of photoautotrophic microalgae. In Chemicals from Microalgae; Routledge: London, UK, 1999; pp. 353-386.

106. Abreu, A.P.; Fernandes, B.; Vicente, A.; Teixeira, J.; Dragone, G. Mixotrophic cultivation of Chlorella vulgaris using industrial dairy waste as organic carbon source. Bioresour. Technol. 2012, 118, 61-66. [CrossRef]

107. Abou-Shanab, R.A.; Ji, M.-K.; Kim, H.-C.; Paeng, K.-J.; Jeon, B.-H. Microalgal species growing on piggery wastewater as a valuable candidate for nutrient removal and biodiesel production. J. Environ. Manag. 2013, 115, 257-264. [CrossRef]

108. Ruiz-Martinez, A.; Garcia, N.M.; Romero, I.; Seco, A.; Ferrer, J. Microalgae cultivation in wastewater: Nutrient removal from anaerobic membrane bioreactor effluent. Bioresour. Technol. 2012, 126, 247-253. [CrossRef]

109. AlMomani, F.A.; Örmeci, B. Performance of Chlorella Vulgaris, Neochloris Oleoabundans, and mixed indigenous microalgae for treatment of primary effluent, secondary effluent and centrate. Ecol. Eng. 2016, 95, 280-289. [CrossRef]

110. Marbelia, L.; Bilad, M.R.; Passaris, I.; Discart, V.; Vandamme, D.; Beuckels, A.; Muylaert, K.; Vankelecom, I.F. Membrane photobioreactors for integrated microalgae cultivation and nutrient remediation of membrane bioreactors effluent. Bioresour. Technol. 2014, 163, 228-235. [CrossRef] [PubMed]

111. Znad, H.; Al Ketife, A.M.; Judd, S.; AlMomani, F.; Vuthaluru, H.B. Bioremediation and nutrient removal from wastewater by Chlorella vulgaris. Ecol. Eng. 2018, 110, 1-7. [CrossRef] 
112. Lam, M.K.; Lee, K.T. Effect of carbon source towards the growth of Chlorella vulgaris for $\mathrm{CO}_{2}$ bio-mitigation and biodiesel production. Int. J. Greenh. Gas Control 2013, 14, 169-176. [CrossRef]

113. Li, J.; Xu, N.S.; Su, W.W. Online estimation of stirred-tank microalgal photobioreactor cultures based on dissolved oxygen measurement. Biochem. Eng. J. 2003, 14, 51-65. [CrossRef]

114. Doucha, J.; Straka, F.; Lívanský, K. Utilization of flue gas for cultivation of microalgae Chlorella sp.) in an outdoor open thin-layer photobioreactor. J. Appl. Phycol. 2005, 17, 403-412. [CrossRef]

115. Ugwu, C.; Aoyagi, H.; Uchiyama, H. Influence of irradiance, dissolved oxygen concentration, and temperature on the growth of Chlorella sorokiniana. Photosynthetica 2007, 45, 309-311. [CrossRef]

116. Singh, S.P.; Singh, P. Effect of $\mathrm{CO}_{2}$ concentration on algal growth: A review. Renew. Sustain. Energy Rev. 2014, 38, 172-179. [CrossRef]

117. Seckbach, J.; Gross, H.; Nathan, M. Growth and photosynthesis of Cyanidium caldarium cultured under pure $\mathrm{CO}_{2}$. Isr. J. Bot. 1971, 20, 84-90.

118. Hanagata, N.; Takeuchi, T.; Fukuju, Y.; Barnes, D.J.; Karube, I. Tolerance of microalgae to high $\mathrm{CO}_{2}$ and high temperature. Phytochemistry 1992, 31, 3345-3348. [CrossRef]

119. Maeda, K.; Owada, M.; Kimura, N.; Omata, K.; Karube, I. $\mathrm{CO}_{2}$ fixation from the flue gas on coal-fired thermal power plant by microalgae. Energy Convers. Manag. 1995, 6, 717-720. [CrossRef]

120. Hirata, S.; Hayashitani, M.; Taya, M.; Tone, S. Carbon dioxide fixation in batch culture of Chlorella sp. using a photobioreactor with a sunlight-cellection device. J. Ferment. Bioeng. 1996, 81, 470-472. [CrossRef]

121. Nakano, Y.; Miyatake, K.; Okuno, H.; Hamazaki, K.; Takenaka, S.; Honami, N.; Kiyota, M.; Aiga, I.; Kondo, J. Growth of photosynthetic algae Euglena in high $\mathrm{CO}_{2}$ conditions and its photosynthetic characteristics. In International Symposium on Plant Production in Closed Ecosystems; International Society for Horticultural Science: Leuven, Belgium, 1996; p. 440.

122. Douskova, I.; Doucha, J.; Livansky, K.; Machat, J.; Novak, P.; Umysova, D.; Zachleder, V.; Vitova, M. Simultaneous flue gas bioremediation and reduction of microalgal biomass production costs. Appl. Microbiol. Biotechnol. 2009, 82, 179-185. [CrossRef] [PubMed]

123. Preisig, H.R.; Andersen, R.A. Historical Review of Algal Culturing Techniques. Algal Cult. Tech. 2005, 65, 79-82. [CrossRef]

124. Li, Y.; Horsman, M.; Wu, N.; Lan, C.Q.; Dubois-Calero, N. Biofuels from microalgae. Biotechnol. Prog. 2008, 24, 815-820. [CrossRef]

125. Young, E.B.; Beardall, J. Photosynthetic function in Dunaliella tertiolecta (Chlorophyta) during a nitrogen starvation and recovery cycle. J. Phycol. 2003, 39, 897-905. [CrossRef]

126. Çelekli, A.; Yavuzatmaca, M.; Bozkurt, H. Modeling of biomass production by Spirulina platensis as function of phosphate concentrations and $\mathrm{pH}$ regimes. Bioresour. Technol. 2009, 100, 3625-3629. [CrossRef]

127. Harkness, J.; Dwyer, G.S.; Warner, N.R.; Parker, K.M.; Mitch, W.A.; Vengosh, A. Iodide, bromide, and ammonium in hydraulic fracturing and oil and gas wastewaters. Environmental implications. Environ. Sci. Technol. 2015, 49, 1955-1963. [CrossRef]

128. Pate, R.; Klise, G.; Wu, B. Resource demand implications for US algae biofuels production scale-u. Appl. Energy 2011, 88, 3377-3388. [CrossRef]

129. Afkar, E.; Ababna, H.; Fathi, A. Toxicological response of the green alga Chlorella vulgaris, to some heavy metals. Am. J. Environ. Sci. 2010, 6, 230. [CrossRef]

130. Kumar, D.; Gaur, J. Chemical reaction-and particle diffusion-based kinetic modeling of metal biosorption by a Phormidium sp.-dominated cyanobacterial mat. Bioresour. Technol. 2011, 102, 633-640. [CrossRef]

131. Calderón-Delgado, I.C.; Mora-Solarte, D.A.; Velasco-Santamaría, Y.M. Physiological and enzymatic responses of Chlorella vulgaris exposed to produced water and its potential for bioremediation. Environ. Monit. Assess. 2019, 191, 399. [CrossRef]

132. Ojagh, S.M.A.; Fallah, N.; Nasernejad, B. Biological treatment of organic compounds in produced water with use of halotolerant bacteria. J. Environ. Chem. Eng. 2020, 8, 104412. [CrossRef]

133. Ammar, S.H.; Khadim, H.J.; Mohamed, A.I. Cultivation of Nannochloropsis oculata and Isochrysis galbana microalgae in produced water for bioremediation and biomass production. Environ. Technol. Innov. 2018, 10, 132-142. [CrossRef]

134. Rahman, A.; Pan, S.; Houston, C.; Selvaratnam, T. Evaluation of Galdieria sulphuraria and Chlorella vulgaris for the bioremediation of produced water. Water 2021, 13, 1183. [CrossRef]

135. Sastre, R.R.; Csögör, Z.; Perner-Nochta, I.; Fleck-Schneider, P.; Posten, C. Scale-down of microalgae cultivations in tubular photo-bioreactors-A conceptual approach. J. Biotechnol. 2007, 132, 127-133. [CrossRef] [PubMed]

136. Rajvanshi, M.; Sayre, R. Recent advances in algal biomass production. In Biomass; InTech Open: London, UK, 2020.

137. Kumar, K.; Mishra, S.K.; Shrivastav, A.; Park, M.S.; Yang, J.-W. Recent trends in the mass cultivation of algae in raceway ponds. Renew. Sustain. Energy Rev. 2015, 51, 875-885. [CrossRef]

138. White, R.L.; Ryan, R.A. Long-term cultivation of algae in open-raceway ponds: Lessons from the field. Ind. Biotechnol. 2015, 11, 213-220. [CrossRef]

139. Vadlamani, A.; Viamajala, S.; Pendyala, B.; Varanasi, S. Cultivation of microalgae at extreme alkaline pH conditions: A novel approach for biofuel production. ACS Sustain. Chem. Eng. 2017, 5, 7284-7294. [CrossRef]

140. Mathimani, T.; Mallick, N. A comprehensive review on harvesting of microalgae for biodiesel-Key challenges and future directions. Renew. Sustain. Energy Rev. 2018, 91, 1103-1120. [CrossRef]

141. Mathimani, T.; Uma, L.; Prabaharan, D. Formulation of low-cost seawater medium for high cell density and high lipid content of Chlorella vulgaris BDUG 91771 using central composite design in biodiesel perspective. J. Clean. Prod. 2018, 198, 575-586. [CrossRef]

142. Hsieh, C.-H.; Wu, W.-T. Cultivation of microalgae for oil production with a cultivation strategy of urea limitation. Bioresour. Technol. 2009, 100, 3921-3926. [CrossRef] 
143. Ullah, K.; Ahmad, M.; Sofia; Sharma, V.K.; Lu, P.; Harvey, A.; Zafar, M.; Sultana, S. Assessing the potential of algal biomass opportunities for bioenergy industry: A review. Fuel 2015, 143, 414-423. [CrossRef]

144. Jay, M.; Kawaroe, M.; Effendi, H. Lipid and fatty acid composition microalgae Chlorella vulgaris using photobioreactor and open pond. IOP Conf Ser. Earth Environ Sci. 2018, 141, 012015. [CrossRef]

145. Grobbelaar, J.U. Factors governing algal growth in photobioreactors: The "open" versus "closed" debate. J. Appl. Phycol. 2008, 21, 489. [CrossRef]

146. Jerney, J.; Spilling, K. Large scale cultivation of microalgae: Open and closed systems. In Biofuels from Algae; Springer: Berlin/Heidelberg, Germany, 2018; pp. 1-8.

147. Richmond, A. Handbook of Microalgal Culture: Biotechnology and Applied Phycology; John Wiley \& Sons: Hoboken, NJ, USA, 2008.

148. Lee, Y.-K. Microalgal mass culture systems and methods: Their limitation and potential. J. Appl. Phycol. 2001, 13, 307-315. [CrossRef]

149. Carvalho, A.P.; Meireles, L.A.; Malcata, F.X. Microalgal reactors: A review of enclosed system designs and performances. Biotechnol. Progr. 2006, 22, 1490-1506. [CrossRef]

150. Shurair, M.S. Photobioreator Technology for Carbon Capture and Nutrients Removal. Ph.D. Thesis, Qatar University, Doha, Qatar, 2017.

151. Elrayies, G.M. Microalgae: Prospects for greener future buildings. Renew. Sustain. Energy Rev. 2018, 81, 1175-1191. [CrossRef]

152. SundarRajan, P.; Gopinath, K.P.; Greetham, D.; Antonysamy, A.J. A review on cleaner production of biofuel feedstock from integrated $\mathrm{CO}_{2}$ sequestration and wastewater treatment system. J. Clean. Prod. 2019, 210, 445-458. [CrossRef]

153. Laksono, S.; ElSherbiny, I.M.; Huber, S.A.; Panglisch, S. Fouling scenarios in hollow fiber membranes during mini-plant filtration tests and correlation to microalgae-loaded feed characteristics. Chem. Eng. J. 2020, 420, 127723. [CrossRef]

154. Zhao, Z.; Muylaert, K.; Vankelecom, I.F. Combining patterned membrane filtration and flocculation for economical microalgae harvesting. Water Res. 2021, 198, 117181. [CrossRef]

155. Najjar, Y.S.; Abu-Shamleh, A. Harvesting of microalgae by centrifugation for biodiesel production: A review. Algal Res. 2020, 51, 102046. [CrossRef]

156. Abu-Shamleh, A.; Najjar, Y.S. Optimization of mechanical harvesting of microalgae by centrifugation for biofuels production Biomass Bioenergy 2020, 143, 105877. [CrossRef]

157. Dassey, A.J.; Theegala, C.S. Harvesting economics and strategies using centrifugation for cost effective separation of microalgae cells for biodiesel applications. Bioresour. Technol. 2013, 128, 241-245. [CrossRef]

158. Landels, A.; Beacham, T.A.; Evans, C.T.; Carnovale, G.; Raikova, S.; Cole, I.; Goddard, P.; Chuck, C.; Allen, M.J. Improving electrocoagulation floatation for harvesting microalgae. Algal Res. 2019, 39, 101446. [CrossRef] [PubMed]

159. Neto, A.M.P.; de Souza, R.A.S.; Leon-Nino, A.D.; da Costa, J.D.a.A.; Tiburcio, R.S.; Nunes, T.A.; de Mello, T.C.S.; Kanemoto, F.T.; Saldanha-Corrêa, F.M.P.; Gianesella, S.M.F. Improvement in microalgae lipid extraction using a sonication-assisted method. Renew. Energy 2013, 55, 525-531. [CrossRef]

160. Giovannoni, S.J.; DeLong, E.F.; Schmidt, T.M.; Pace, N.R. Tangential flow filtration and preliminary phylogenetic analysis of marine picoplankton. Appl. Environ. Microbiol. 1990, 56, 2572. [CrossRef] [PubMed]

161. Brennan, L.; Owende, P. Biofuels from microalgae-A review of technologies for production, processing, and extractions of biofuels and co-products. Renew. Sustain. Energy Rev. 2010, 14, 557-577. [CrossRef]

162. Schenk, P.M.; Thomas-Hall, S.R.; Stephens, E.; Marx, U.C.; Mussgnug, U.C.M.J.H.; Posten, C.; Kruse, O.; Hankamer, B. Second generation biofuels: High-efficiency microalgae for biodiesel production. Bioenergy Res. 2008, 1, 20-43. [CrossRef]

163. Muñoz, R.; Guieysse, B. Algal-bacterial processes for the treatment of hazardous contaminants: A review. Water Res. 2006, 40, 2799-2815. [CrossRef] [PubMed]

164. Lee, D.-H.; Bae, C.Y.; Han, J.-I.; Park, J.-K. In situ analysis of heterogeneity in the lipid content of single green microalgae in alginate hydrogel microcapsules. Anal. Chem. 2013, 85, 8749-8756. [CrossRef]

165. Divakaran, R.; Pillai, V.S. Flocculation of river silt using chitosan. Water Res. 2002, 36, 2414-2418. [CrossRef]

166. Bosma, R.; Van Spronsen, W.A.; Tramper, J.; Wijffels, R.H. Ultrasound, a new separation technique to harvest microalgae. J. Appl. Phycol. 2003, 15, 143-153. [CrossRef]

167. Gröschl, M. Ultrasonic separation of suspended particles-Part I: Fundamentals. Acta Acust. 1998, 84, $432-447$.

168. Deshmukh, S.; Kumar, R.; Bala, K. Microalgae biodiesel: A review on oil extraction, fatty acid composition, properties and effect on engine performance and emissions. Fuel Process. Technol. 2019, 191, 232-247. [CrossRef]

169. Menegazzo, M.L.; Fonseca, G.G. Biomass recovery and lipid extraction processes for microalgae biofuels production: A review. Renew. Sustain. Energy Rev. 2019, 107, 87-107. [CrossRef]

170. Vasistha, S.; Khanra, A.; Clifford, M.; Rai, M. Current advances in microalgae harvesting and lipid extraction processes for improved biodiesel production: A review. Renew. Sustain. Energy Rev. 2020, 107, 110498. [CrossRef]

171. Folch, J.; Lees, M.; Stanley, G.S. A simple method for the isolation and purification of total lipides from animal tissues. J. Biol. Chem. 1957, 226, 497-509. [CrossRef]

172. Bligh, E.G.; Dyer, W.J. A rapid method of total lipid extraction and purification. Can. J. Biochem. Physiol. 1959, 37, 911-917. [CrossRef]

173. Sierra, L.S.; Dixon, C.K.; Wilken, L.R. Enzymatic cell disruption of the microalgae Chlamydomonas reinhardtii for lipid and protein extraction. Algal Res. 2017, 25, 149-159. [CrossRef]

174. Zhang, Y.; Kong, X.; Wang, Z.; Sun, Y.; Zhu, S.; Li, L.; Lv, P. Optimization of enzymatic hydrolysis for effective lipid extraction from microalgae Scenedesmus sp. Renew. Energy 2018, 125, 1049-1057. [CrossRef] 
175. Gerde, J.A.; Montalbo-Lomboy, M.; Yao, L.; Grewell, D.; Wang, T. Evaluation of microalgae cell disruption by ultrasonic treatment. Bioresour. Technol. 2012, 125, 175-181. [CrossRef]

176. Faerman, V.; Mukmenev, I.; Shreiber, I. Sonication of microalgae and its precipitation. Acta Acust. 2002, 88, 592-593.

177. Dai, Y.-M.; Chen, K.-T.; Chen, C.-C. Study of the microwave lipid extraction from microalgae for biodiesel production. Chem. Eng. J. 2014, 250, 267-273. [CrossRef]

178. Onumaegbu, C.; Alaswad, A.; Rodriguez, C.; Olabi, A. Modelling and optimization of wet microalgae Scenedesmus quadricauda lipid extraction using microwave pre-treatment method and response surface methodology. Renew. Energy 2019, 132, 1323-1331. [CrossRef]

179. Teo, C.L.; Idris, A. Enhancing the various solvent extraction method via microwave irradiation for extraction of lipids from marine microalgae in biodiesel production. Bioresour. Technol. 2014, 171, 477-481. [CrossRef]

180. González-González, L.M.; Astals, S.; Pratt, S.; Jensen, P.D.; Schenk, P.M. Impact of osmotic shock pre-treatment on microalgae lipid extraction and subsequent methane production. Bioresour. Technol. Rep. 2019, 7, 100214. [CrossRef]

181. González-González, L.M.; Astals, S.; Pratt, S.; Jensen, P.D.; Schenk, P.M. Osmotic shock pre-treatment of Chaetoceros muelleri wet biomass enhanced solvent-free lipid extraction and biogas production. Algal Res. 2021, 54, 102177. [CrossRef]

182. Grimi, N.; Dubois, A.; Marchal, L.; Jubeau, S.; Lebovka, N.; Vorobiev, E. Selective extraction from microalgae Nannochloropsis susing different methods of cell disruption. Bioresour. Technol. 2014, 153, 254-259. [CrossRef] [PubMed]

183. Lee, J.-Y.; Yoo, C.; Jun, S.-Y.; Ahn, C.-Y.; Oh, H.-M. Comparison of several methods for effective lipid extraction from microalgae. Bioresour. Technol. 2010, 101, S75-S77. [CrossRef] [PubMed]

184. Yang, J.; Yang, L. A review on hydrothermal co-liquefaction of biomass. Appl. Energy 2019, 250, 926-945. [CrossRef]

185. Gu, X.; Martinez-Fernandez, J.; Pang, N.; Fu, X.; Chen, S. Recent development of hydrothermal liquefaction for algal biorefinery. Renew. Sustain. Energy Rev. 2020, 121, 109707. [CrossRef]

186. Guo, Y.; Yeh, T.; Song, W.; Xu, D.; Wang, S. A review of bio-oil production from hydrothermal liquefaction of algae. Renew. Sustain. Energy Rev. 2015, 48, 776-790. [CrossRef]

187. Cui, Z.; Cheng, F.; Jarvis, J.M.; Brewer, C.; Jena, U. Roles of co-solvents in hydrothermal liquefaction of low-lipid, high-protein algae. Bioresour. Technol. 2020, 310, 123454. [CrossRef]

188. Raheem, A.; Ji, G.; Memon, A.; Sivasangar, S.; Wang, W.; Zhao, M.; Taufiq-Yap, Y. Catalytic gasification of algal biomass for hydrogen-rich gas production: Parametric optimization via central composite design. Energy Convers. Manag. 2018, 158, 235-245. [CrossRef]

189. Raheem, A.; Liu, H.; Ji, G.; Zhao, M. Gasification of lipid-extracted microalgae biomass promoted by waste eggshell as CaO catalyst. Algal Res. 2019, 42, 101601. [CrossRef]

190. Yang, C.; Li, R.; Zhang, B.; Qiu, Q.; Wang, B.; Yang, H.; Ding, Y.; Wang, C. Pyrolysis of microalgae: A critical review. Fuel Process. Technol. 2019, 186, 53-72. [CrossRef]

191. Lee, X.J.; Ong, H.C.; Gan, Y.Y.; Chen, W.-H.; Mahlia, T.M.I. State of art review on conventional and advanced pyrolysis of macroalgae and microalgae for biochar, bio-oil and bio-syngas production. Energy Convers. Manag. 2020, 210, 112707. [CrossRef]

192. Hu, Z.; Ma, X.; Li, L. The characteristic and evaluation method of fast pyrolysis of microalgae to produce syngas. Bioresour. Technol. 2013, 140, 220-226. [CrossRef] [PubMed]

193. Beneroso, D.; Bermúdez, J.; Arenillas, A.; Menéndez, J. Microwave pyrolysis of microalgae for high syngas production Bioresour. Technol. 2013, 144, 240-246. [CrossRef] [PubMed]

194. Efremenko, E.; Nikolskaya, A.; Lyagin, I.; Sen'Ko, O.; Makhlis, T.; Stepanov, N.; Maslova, O.; Mamedova, F.; Varfolomeev, S. Production of biofuels from pretreated microalgae biomass by anaerobic fermentation with immobilized Clostridium acetobutylicum cells. Bioresour. Technol. 2012, 114, 342-348. [CrossRef] [PubMed]

195. Sun, C.; Xia, A.; Liao, Q.; Fu, Q.; Huang, Y.; Zhu, X. Life-cycle assessment of biohythane production via two-stage anaerobic fermentation from microalgae and food waste. Renew. Sustain. Energy Rev. 2019, 112, 395-410. [CrossRef]

196. Chen, C.; Sun, C.; Xia, A.; Liao, Q.; Guo, X.; Huang, Y.; Fu, Q.; Zhu, X.; Zhu, X. Sustainable biohythane production from algal bloom biomass through two-stage fermentation: Impacts of the physicochemical characteristics and fermentation performance. Int. J. Hydrogen Energy 2020, 45, 27. [CrossRef]

197. Karpagam, R.; Jawaharraj, K.; Gnanam, R. Review on integrated biofuel production from microalgal biomass through the outset of transesterification route: A cascade approach for sustainable bioenergy. Sci. Total Environ. 2021, 766, 144236. [CrossRef]

198. Zhang, X.; Yan, S.; Tyagi, R.; Surampalli, R. Biodiesel production from heterotrophic microalgae through transesterification and nanotechnology application in the production. Renew. Sustain. Energy Rev. 2013, 26, 216-223. [CrossRef]

199. Kim, B.; Heo, H.Y.; Son, J.; Yang, J.; Chang, Y.-K.; Lee, J.H.; Lee, J.W. Simplifying biodiesel production from microalgae via wet in situ transesterification: A review in current research and future prospects. Algal Res. 2019, 41, 101557. [CrossRef]

200. Sivaramakrishnan, R.; Incharoensakdi, A. Utilization of microalgae feedstock for concomitant production of bioethanol and biodiesel. Fuel 2018, 217, 458-466. [CrossRef]

201. Rehman, Z.U.; Anal, A.K. Enhanced lipid and starch productivity of microalga (Chlorococcum sTISTR 8583) with nitrogen limitation following effective pretreatments for biofuel production. Biotechnol. Rep. 2019, 21, e00298. [CrossRef]

202. El-Dalatony, M.M.; Salama, E.-S.; Kurade, M.; Kim, K.-Y.; Govindwar, S.P.; Kim, J.R.; Kwon, E.E.; Min, B.; Jang, M.; Oh, S.-E.; et al Whole conversion of microalgal biomass into biofuels through successive high-throughput fermentation. Chem. Eng. J. 2018, 360, 797-805. [CrossRef]

203. Sun, Z.; Zhou, Z. Nature-inspired virus-assisted algal cell disruption for cost-effective biofuel production. Appl. Energy 2019, 251, 113330. [CrossRef] 
204. Church, J.; Hwang, J.-H.; Kim, K.-T.; McLean, R.; Oh, Y.-K.; Nam, B.; Joo, J.C.; Lee, W.H. Effect of salt type and concentration on the growth and lipid content of Chlorella vulgaris in synthetic saline wastewater for biofuel production. Bioresour. Technol. 2017, 243, 147-153. [CrossRef]

205. Bell, T.A.S.; Doig, L.; Peyton, B.; Gerlach, R.; Fields, M.W. Contributions of the microbial community to algal biomass and biofuel productivity in a wastewater treatment lagoon system. Algal Res. 2019, 39, 101461. [CrossRef]

206. Biswas, B.; Kumar, A.A.; Bisht, Y.; Singh, R.; Kumar, J.; Bhaskar, T. Effects of temperature and solvent on hydrothermal liquefaction of Sargassum tenerrimum algae. Bioresour. Technol. 2017, 242, 344-350. [CrossRef] [PubMed]

207. Rahman, Q.M.; Zhang, B.; Wang, L.; Joseph, G.; Shahbazi, A. A combined fermentation and ethanol-assisted liquefaction process to produce biofuel from Nannochloropsis sp. Fuel 2019, 238, 159-165. [CrossRef]

208. Yang, W.; Li, X.; Zhang, D.; Feng, L. Catalytic upgrading of bio-oil in hydrothermal liquefaction of algae major model components over liquid acids. Energy Convers. Manag. 2017, 154, 336-343. [CrossRef]

209. Hanchate, N.; Ramani, S.; Mathpati, C.; Dalvi, V.H. Biomass gasification using dual fluidized bed gasification systems: A review. J. Clean. Prod. 2020, 280, 123148. [CrossRef]

210. Soares, R.B.; Martins, M.F.; Gonçalves, R.F. Experimental investigation of wastewater microalgae in a pilot-scale downdraft gasifier. Algal Res. 2020, 51, 102049. [CrossRef]

211. Xu, D.; Liu, L.; Wei, N.; Guo, Y.; Wang, S.; Wu, Z.; Duan, P. Catalytic supercritical water gasification of aqueous phase directly derived from microalgae hydrothermal liquefaction. Int. J. Hydrogen Energy 2019, 44, 26181-26192. [CrossRef]

212. Ashokkumar, V.; Chen, W.-H.; Kamyab, H.; Kumar, G.; Ala'a, H.; Ngamcharussrivichai, C. Cultivation of microalgae Chlorella sin municipal sewage for biofuel production and utilization of biochar derived from residue for the conversion of hematite iron ore $\left(\mathrm{Fe}_{2} \mathrm{O}_{3}\right)$ to iron (Fe)-Integrated algal biorefinery. Energy 2019, 189, 116128. [CrossRef]

213. Wang, S.; Hu, S.; Shang, H.; Barati, B.; Gong, X.; Hu, X.; Abomohra, A.E.-F. Study on the co-operative effect of kitchen wastewater for harvest and enhanced pyrolysis of microalgae. Bioresour. Technol. 2020, 317, 123983. [CrossRef]

214. Du, Z.; Li, Y.; Wang, X.; Wan, Y.; Chen, Q.; Wang, C.; Lin, X.; Liu, Y.; Chen, P.; Ruan, R. Microwave-assisted pyrolysis of microalgae for biofuel production. Bioresour. Technol. 2011, 102, 4890-4896. [CrossRef]

215. Choi, D.; Nam, I.-H.; Park, Y.-K.; Ok, Y.S.; Lee, J.; Kwon, E.E. Catalytic pyrolysis of brown algae using carbon dioxide and oyster shell. J. $\mathrm{CO}_{2}$ Util. 2019, 34, 668-675. [CrossRef]

216. Hu, Z.; Ma, X.; Li, L.; Wu, J. The catalytic pyrolysis of microalgae to produce syngas. Energy Convers. Manag. 2014, 85, 545-550. [CrossRef]

217. Ho, S.-H.; Huang, S.-W.; Chen, C.-Y.; Hasunuma, T.; Kondo, A.; Chang, J.-S. Bioethanol production using carbohydrate-rich microalgae biomass as feedstock. Bioresour. Technol. 2013, 135, 191-198. [CrossRef]

218. Llamas, M.; Magdalena, J.A.; Tomás-Pejó, E.; González-Fernández, C. Microalgae-based anaerobic fermentation as a promising technology for producing biogas and microbial oils. Energy 2020, 206, 118184. [CrossRef]

219. David, B.; Federico, B.; Cristina, C.; Marco, G.; Federico, M.; Paolo, P. Biohythane production from food wastes. In Biohydrogen; Elsevier: Amsterdam, The Netherlands, 2019; pp. 347-368.

220. Salaeh, S.; Kongjan, P.; Panphon, S.; Hemmanee, S.; Reungsang, A.; Jariyaboon, R. Feasibility of ABE fermentation from Rhizoclonium sphydrolysate with low nutrient supplementation. Biomass Bioenergy 2019, 127, 105269. [CrossRef]

221. Ha, G.-S.; El-Dalatony, M.M.; Kurade, M.B.; Salama, E.-S.; Basak, B.; Kang, D.; Roh, H.-S.; Lim, H.; Jeon, B.-H. Energy-efficient pretreatments for the enhanced conversion of microalgal biomass to biofuels. Bioresour. Technol. 2020, 309, 123333. [CrossRef] [PubMed]

222. Serrà, A.; Artal, R.; García-Amorós, J.; Gómez, E.; Philippe, L. Circular zero-residue process using microalgae for efficient water decontamination, biofuel production, and carbon dioxide fixation. Chem. Eng. J. 2020, 388, 124278. [CrossRef]

223. Deng, C.; Lin, R.; Kang, X.; Wu, B.; O'Shea, R.; Murphy, J.D. Improving gaseous biofuel yield from seaweed through a cascading circular bioenergy system integrating anaerobic digestion and pyrolysis. Renew. Sustain. Energy Rev. 2020, 128, 109895. [CrossRef]

224. Chandra, N.; Shukla, P.; Mallick, N. Role of cultural variables in augmenting carbohydrate accumulation in the green microalga Scenedesmus acuminatus for bioethanol production. Biocatal. Agric. Biotechnol. 2020, 26, 101632. [CrossRef]

225. Karthikeyan, S.; Periyasamy, M.; Prathima, A. Combustion analysis of a CI engine with Caulerpa racemosa algae biofuel with nano additives. Mater. Today Proc. 2020, 33, 3324-3329. [CrossRef]

226. Shwetharani, R.; Balakrishna, R.G. Efficient algal lipid extraction via photocatalysis and its conversion to biofuel. Appl. Energy 2016, 168, 364-374. [CrossRef]

227. Vignesh, N.S.; Vimali, E.; Sangeetha, R.; Arumugam, M.; Ashokkumar, B.; Ganeshmoorthy, I.; Varalakshmi, P. Sustainable biofuel from microalgae: Application of lignocellulosic wastes and bio-iron nanoparticle for biodiesel production. Fuel 2020, 278, 118326. [CrossRef]

228. Hess, D.; Quinn, J.C. Impact of inorganic contaminants on microalgal biofuel production through multiple conversion pathways. Biomass Bioenergy 2018, 119, 237-245. [CrossRef]

229. Phukan, M.M.; Hazarika, N.; Bora, P.; Borah, T.; Konwar, B.K. Leveraging microalga feedstock for biofuel production and wasteland reclamation using remote sensing and ex situ experimentation. Renew. Energy 2020, 159, 973-981. [CrossRef]

230. Dogaris, I.; Loya, B.; Cox, J.; Philippidis, G. Study of landfill leachate as a sustainable source of water and nutrients for algal biofuels and bioproducts using the microalga Picochlorum oculatum in a novel scalable bioreactor. Bioresour. Technol. 2019, 282, 18-27. [CrossRef] [PubMed] 